\title{
SOCIEDADE, NATUREZA E REFORMA AGRÁRIA: ASSENTAMENTOS RURAIS E UNIDADES DE CONSERVAÇÃO NA REGIÃO DO PONTAL DO PARANAPANEMA
}

\author{
Luiz Carlos Beduschi Filho
}

Dissertação apresentada ao Programa de Pós-Graduação em Ciência Ambiental da Universidade de São Paulo como parte dos requisitos para a obtenção do título de Mestre em Ciência Ambiental.

ORIENTADOR - Ricardo Abramovay Professor titular - PROCAM e Departamento de Economia da FEA/USP

São Paulo 
À Líviam, companheira de todas as horas e de todos os sonhos. 


\section{Agradecimentos}

Ao professor Ricardo Abramovay, pela excelente orientação durante o trabalho de elaboração da dissertação.

Aos meus pais, Luiz Carlos e Lúcia, meus primeiros e grandes professores, pelo seu constante apoio às minhas decisões e pelo carinho que sempre me dedicaram.

Ao Instituto de Pesquisas Ecológicas, pelo exemplo de seriedade e dedicação na busca de novas formas de convivência entre sociedade e natureza.

Aos companheiros do Movimento dos Trabalhadores Rurais Sem Terra do Pontal do Paranapanema pela coragem de tentar fazer uma reforma agrária sustentável.

Às famílias assentadas na Gleba Ribeirão Bonito, pela solicitude que sempre me dispensaram ao longo da pesquisa.

A todos os colegas, professores e funcionários do Programa de Pós-Graduação em Ciência Ambiental/USP.

À Fundação de Amparo à Pesquisa do Estado de São Paulo, pela bolsa de estudo concedida.

Ao WWF, pelo apoio ao projeto através do Programa Natureza e Sociedade. 


\section{SUMÁRIO}

LISTA DE ABREVIATURAS E SIGLAS..............................................................

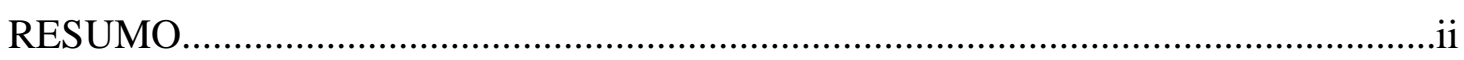

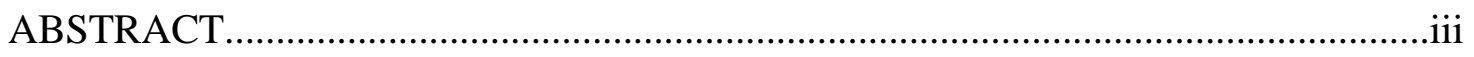

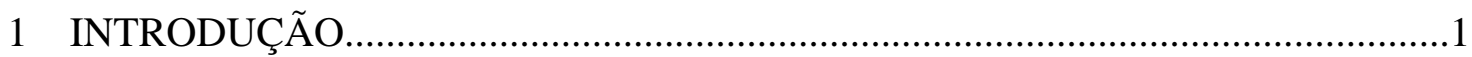

2 REFORMA AGRÁRIA E MEIO AMBIENTE NO PONTAL

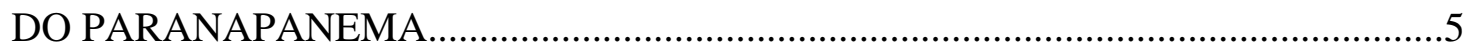

3 CONSTRUINDO O PROBLEMA DE PESQUISA ..................................................

3.1 Construindo o problema de pesquisa e a hipótese central............................................

3.2 Fundamentos de Biologia da Conservação e sua aplicação na região do Pontal

do Paranapanema................................................................................................12

3.3 A construção social da questão ambiental no Pontal do Paranapanema.......................15

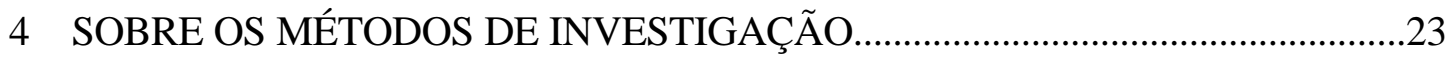

5 AÇÃO COLETIVA E INSTITUIÇÕES NO PONTAL DO PARANAPANEMA....27

6 EVIDÊNCIAS EMPÍRICAS DO ESTUDO DE CASO................................................49

6.1 As principais transformações nas práticas de manejo dos lotes pelas

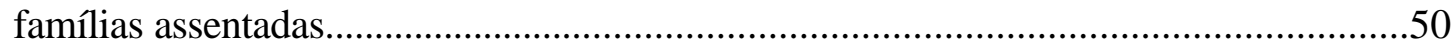

6.2 A estrutura de incentivos para as transformações nas relações entre



6.3 Conservação da Natureza: moda passageira ou uma nova instituição?.......................67

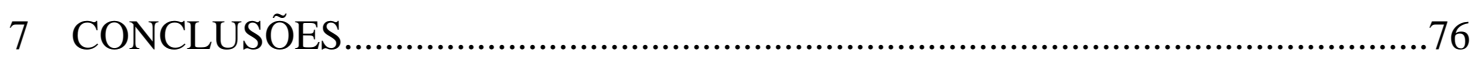

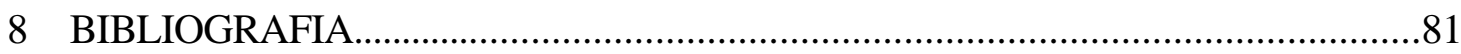

9 APÊNDICE 


\section{LISTA DE ABREVIATURAS E SIGLAS}

AS-PTA - Assessoria e Serviços em Projetos de Tecnologia Alternativa CESP - Companhia Energética de São Paulo COCAMP - Cooperativa de comercialização e prestação de serviços dos assentados de reforma agrária do Pontal do Paranapanema.

ESALQ - Escola Superior de Agricultura "Luiz de Queiroz"

IF - Instituto Florestal

INCRA - Instituto Nacional de Colonização e Reforma Agrária

IPE - Instituto de Pesquisas Ecológicas

ITESP - Fundação Instituto de Terras "José Gomes da Silva" do Estado de São Paulo

MST - Movimento dos Trabalhadores Rurais Sem Terra

ONG - Organização não governamental

PEMD - Parque Estadual do Morro do Diabo

SMA - Secretaria Estadual de Meio Ambiente

USP - Universidade de São Paulo 


\section{RESUMO}

BEDUSCHI FILHO, L. C. (2002). Sociedade, natureza e reforma agrária: assentamentos rurais e unidades de conservação na região do Pontal do Paranapanema. São Paulo, 2002. 97p. Dissertação de Mestrado. Programa de PósGraduação em Ciência Ambiental da Universidade de São Paulo.

As famílias assentadas na Gleba Ribeirão Bonito, que vivem ao lado do Parque Estadual do Morro do Diabo, estão, ao contrário do que se poderia esperar, contribuindo, através de projetos articulados por uma rede de organizações, para a conservação dos recursos naturais desta Unidade de Conservação. A dissertação explora os fatores que têm condicionado tal realidade, fundamentando-se nas contribuições teóricas da economia das instituições e da sociologia ambiental. A conclusão é que está em processo de construção, na região do Pontal do Paranapanema, uma nova instituição que pode contribuir para a promoção de um modelo de desenvolvimento regional que inclua, ao mesmo tempo, o desenvolvimento social e econômico das famílias assentadas e a conservação da natureza.

Palavras-chave: assentamentos rurais; conservação da natureza; sociologia ambiental; economia institucional. 


\begin{abstract}
BEDUSCHI FILHO, L.C. (2002). Society, nature and land reform: rural planned settelments and conservation areas in Pontal do Paranapanema region. São Paulo, 2002. 97p. Dissertação de Mestrado. Programa de Pós-Graduação em Ciência Ambiental da Universidade de São Paulo.
\end{abstract}

The families seated in the Gleba Ribeirão Bonito, who live to the side of the Morro do Diabo State Park, are, in contrast of that we could wait, contributing, through designs articulated for a network of organizations, for the conservation of the natural features of this Unit of Conservation. The text explores the factors that condition such reality, basing itself on the theoretical contributions of the institutional economics and environmental sociology. The conclusion is that it is in construction process, in the region of the Pontal of the Paranapanema, a new institution that can contribute for the promotion of a model of regional development that includes, at the same time, the social and economic development of the seated families and the conservation of the nature.

Keywords: rural settelments; nature conservation; environmental sociology; institutional economics. 


\section{INTRODUÇÃO}

Estavam reunidos todos os ingredientes da destruição anunciada: um grupo de assentados, vivendo em situação de extrema pobreza, cansados da luta pela terra e ansiosos por cultivar o necessário à sua sobrevivência e seu desenvolvimento; um parque natural altamente propício (após a sua derrubada) para o exercício de atividades agropecuárias e fonte quase inesgotável de madeira e de caça; quase ausência de policiamento. Contrariamente ao que se poderia acreditar, entretanto, passados mais de quatro anos da instalação definitiva dos agricultores da Gleba Ribeirão Bonito, a profecia não se cumpriu: hoje o Parque está preservado, em parte graças aos esforços dos agricultores assentados, que conseguiram transformar a convivência com a natureza em fonte de renda.

\section{Utopia?}

Muito pelo contrário! Essa é a realidade que está transformando o Pontal do Paranapanema, muito conhecido por seus conflitos fundiários, em um dos mais promissores exemplos da construção de um modelo alternativo de convivência harmônica entre assentamentos rurais e áreas naturais .

Compreender como foi (e está sendo) construída essa nova realidade é o objetivo principal desta dissertação de mestrado.

Por que as famílias assentadas não começaram o processo de degradação dos recursos naturais, já que agora são "vizinhas de cerca" de uma floresta de 35.000 ha ? 
Por que, ao invés de destruírem, através do uso descontrolado, os recursos naturais, essas famílias estão ajudando a conservá-los? O que faz com que elas refutem, através das suas práticas, a hipótese da "tragédia dos comuns", formulada por Hardin (1968)?

As respostas para estas perguntas podem ser agrupadas na seguinte hipótese: é a existência de uma estrutura de incentivos, dada pela ação de uma rede de trabalho que envolve organizações ambientalistas não governamentais, organismos estatais de preservação ambiental, universidade, cooperativa de assentados e movimento social, que está levando as famílias de agricultores assentadas a estabelecer novas formas de relacionamento com a Natureza.

Dessa forma, a dissertação desvenda essa rede de trabalho e demonstra que os incentivos que ela disponibiliza para as famílias de agricultores assentadas no entorno do Parque Estadual do Morro do Diabo têm feito com que transformações significativas na relação entre sociedade e natureza aconteçam na região.

Para desvendar essa rede de trabalho e a estrutura de incentivos que ela disponibiliza para as famílias assentadas os principais instrumentos teóricos e metodológicos utilizados foram a sociologia ambiental, que trata especialmente da construção social das questões ambientais, e a economia das instituições, que tem entre os seus principais problemas de investigação a lógica da ação coletiva.

Assim, no capítulo 2, é apresentado um breve histórico da evolução da questão agrária no Pontal do Paranapanema, associando a formação e consolidação dos assentamentos rurais com a questão ambiental na região. $\mathrm{O}$ objetivo principal deste capítulo é demonstrar que o processo de regularização fundiária no Pontal tem 
relação direta com as possibilidades de preservação dos recursos naturais desta região.

Em seguida, no capítulo 3, é apresentada a construção do problema de pesquisa, de forma mais estruturada do que nesta introdução. Nele, o leitor é convidado a conhecer uma das principais correntes científicas das ciências naturais que tem grande influência na construção de estratégias de conservação ambiental na região: a biologia da conservação, ao introduzir o conceito de paisagem, permite que se ampliem os horizontes da conservação, incorporando de maneira definitiva as comunidades humanas no processo de preservação ambiental. Neste capítulo, ainda, é investigado o processo de construção social da questão ambiental na região do Pontal do Paranapanema, são apresentados os principais atores sociais e as arenas de disputa onde se negociam os conflitos entre eles. É a partir da negociação destes conflitos que se forma a rede de organizações que vai influenciar as famílias assentadas. É também essa negociação que vai, aos poucos, modificando o sentido da ação de cada um dos integrantes da rede.

O capítulo 4 expõe os procedimentos de investigação, demonstrando os principais aspectos metodológicos que sustentaram a condução da pesquisa.

Tendo apresentado os principais atores sociais $\mathrm{e}$ os procedimentos metodológicos, a dissertação entra definitivamente na discussão teórica que relaciona ações coletivas e instituições. A economia das instituições mostrou-se um campo teórico extremamente fértil para a compreensão da lógica da ação coletiva, em especial por aproximar-se bastante das correntes sociológicas que lidam com a construção de redes. Neste capítulo, então, o leitor vai poder acompanhar o diálogo com diversos autores que ajudam a compreender melhor o que está acontecendo na 
região do Pontal do Paranapanema. Do trabalho de Mancur Olson (1965) sobre a lógica da ação coletiva, até os trabalhos recentes de Elinor Ostrom (1990) sobre o governo dos comuns, passando pelas contribuições de Coleman (1990), North (1990) e Bicchieri (1997), o capítulo 5 é o "recheio" da dissertação. Nele são discutidas as questões da coordenação da ação coletiva e o surgimento de instituições que podem balizar a ação individual, reduzir a incerteza dos atores e contribuir para a acumulação de capital social.

Tendo apresentado as contribuições teóricas da economia das instituições, no capítulo 6 são demonstradas as principais evidências empíricas que corroboram a hipótese central do trabalho. As principais transformações nas práticas de manejo dos lotes pelas famílias assentadas são apresentadas, a estrutura de incentivos que a rede de organizações disponibiliza para as famílias assentadas é evidenciada e uma discussão sobre o surgimento de uma nova instituição (seria a conservação da natureza apenas uma moda passageira? ) tem início.

Finalmente, no capítulo 7 , são apresentadas as conclusões da pesquisa e elaboradas algumas recomendações que podem contribuir para o esforço de aliar a conservação dos recursos naturais ao desenvolvimento social e econômico das famílias assentadas na região do Pontal do Paranapanema. 


\section{2- REFORMA AGRÁRIA E MEIO AMBIENTE NO PONTAL DO PARANAPANEMA}

A região do Pontal do Paranapanema tornou-se amplamente conhecida depois que se transformou no palco de intensos conflitos fundiários a partir da década de 90, consequiência do processo fraudulento de ocupação das terras que teve origem no final do século XIX.

A "descoberta" do Pontal pelos movimentos sociais que demandavam terra fez com que a questão agrária fosse retomada e trazida à baila de forma definitiva no Brasil, principalmente pela atenção despendida pelos meios de comunicação aos conflitos que passaram a ocorrer com maior freqüência.

Zander Navarro (1997) diz que “...é preciso perceber que a organização dos sem-terra assumiu uma feição nacional somente a partir de sua inserção no Pontal do Paranapanema, quando foi notado por nossas elites e projetou-se às páginas dos principais jornais...".

Os primeiros conflitos fundiários no Pontal começam a ocorrer como conseqüência da construção de barragens de usinas hidrelétricas. A construção destas barragens acabou por desalojar grande quantidade de agricultores, que foram então transferidos, após vários conflitos, para outras áreas. Os assentamentos mais antigos do Pontal, como a Gleba XV de Novembro e o assentamento Lagoa São Paulo, se originaram desse processo, que ocorreu no início da década de 80.

Porém, é só a partir da década de 90 que os trabalhadores efetivamente se organizam e começam a atuar de forma sistemática para a conquista da terra no Pontal. 
A história da ocupação do Pontal do Paranapanema pode ser entendida como uma mistura de imensas fraudes no processo de apropriação privada da terra (Fernandes, 1996) com a devastação acelerada da floresta atlântica (Dean, 1996).

A grilagem de terras no Pontal é hoje uma história amplamente reconhecida. Começou com o "grilo-mãe" Fazenda Pirapó-Santo Anastácio, cuja área era de 583.100 ha, arquitetato em 1886 por João Evangelista de Lima, que fraudou documentos e modificou registros paroquiais. Já na década de 30 o Estado declarou devolutas as terras da fazenda Pirapó -Santo Anastácio e desaconselhava a compra de terras na região (Fernandes, 1996). Porém, várias ocupações foram legalizadas e se constituíram como imensas fazendas agropecuárias.

Para legitimar a posse das terras, iniciou-se, então, um processo voraz de ocupação das florestas da região. Impulsionado pela construção de ferrovias e pela expansão do cultivo do café, assim como em outras regiões do estado, o desmatamento de vastas áreas florestais foi intenso (Dean, 1996).

Como será demonstrado adiante, dos 297.000 ha da Grande Reserva do Pontal, hoje restam pouco mais de 35.000 ha no Parque Estadual do Morro do Diabo e pouco mais de 12.000 ha em fragmentos florestais espalhados pela região.

O que se percebe é que a questão agrária está diretamente associada à questão ambiental na região do Pontal. A única forma de se legitimar a posse de uma terra era a completa derrubada da floresta e a sua transformação em pastagem ou lavoura. A ocupação do espaço no Pontal seguiu essa lógica, legitimada por um arcabouço institucional que indicava para os potenciais ocupantes das terras da região que essa era a forma mais adequada de garantir a posse da terra. 
A construção das barragens para a instalação de usinas hidrelétricas também desempenhou papel fundamental na construção da história do Pontal, tanto do ponto de vista ambiental quanto do ponto de vista da questão agrária.

É a partir da construção da barragem de Rosana que têm início os trabalhos para a conservação de espécies raras, como o mico-leão-preto (Leontopithecus chrysopygus), que serão fundamentais para o entendimento do processo de construção social da questão ambiental na região, como será visto no capítulo seguinte. É também a partir da construção das barragens que começam os conflitos por terra, já que muitos agricultores foram desalojados e posteriormente transferidos para outras áreas. Além disso, com o término das obras, ficou na região um verdadeiro exército de pessoas com baixa qualificação profissional que iriam engrossar as fileiras dos movimentos sociais e demandar um pedaço de terra que garantisse as mínimas condições de sobrevivência.

É também o processo de ocupação desordenada de vastas extensões de terra que acaba por fazer com que, mais uma vez, a questão agrária e a questão ambiental se tangenciem na região do Pontal do Paranapanema.

As áreas destinadas aos assentamentos são originadas da reincorporação pelo Estado de terras devolutas ocupadas de forma irregular por grandes fazendas dedicadas à exploração pecuária extensiva. Ironicamente, estão nestas grandes fazendas os maiores fragmentos florestais da região, que abrigam espécies ameaçadas de extinção como o mico-leão-preto e os grandes mamíferos, como as onças e antas. 
Com o processo de criação e consolidação dos assentamentos rurais nessas fazendas, esses fragmentos florestais passaram a ser circundados por famílias de agricultores que estão buscando formas de garantir a sua sobrevivência na terra.

Mais uma vez, como numa peça de teatro, as questões agrária e ambiental se encontram, desafiando tanto aqueles que pretendem fazer avançar o processo de reforma agrária quanto aqueles que pretendem garantir a conservação da natureza na região.

Dos caminhos trilhados por eles para enfrentar esse desafio é que trata essa dissertação. 


\section{3- CONSTRUINDO O PROBLEMA DE PESQUISA}

Como já foi dito na introdução da dissertação, este capítulo apresenta, de forma mais estruturada, o problema de pesquisa e a hipótese central que orienta o trabalho. Além disso, são apresentados, também, dois campos teóricos que são fundamentais para a compreensão da realidade na região do Pontal. O primeiro deles, no item 3.2, introduz o leitor aos fundamentos da biologia da conservação, que ao privilegiar o conceito de paisagem incorpora de forma definitiva as comunidades humanas nas estratégias de conservação na região. Podemos afirmar que essa é a base conceitual que orienta as ações conservacionistas desenvolvidas atualmente na região. Em seguida, no item 3.3 deste capítulo, investiga-se o processo de construção social da questão ambiental na região do Pontal do Paranapanema. São apresentados aqui os principais atores sociais e as arenas de disputa onde se negociam os conflitos entre eles.

\section{1 - Construindo o problema de pesquisa e a hipótese central}

Se por um lado a literatura relacionada ao manejo de recursos naturais é rica em análises sobre as formas como comunidades consideradas tradicionais utilizam esses recursos, por outro lado não incorpora de forma significativa outros atores sociais que também podem desempenhar um papel fundamental na conservação ou destruição destes ecossistemas (Cunha, 1993). Assim, ao privilegiar uma comunidade formada por famílias de agricultores assentadas, a dissertação amplia a 
discussão acadêmica sobre o tema, levantando novas questões sobre o manejo destas áreas.

A primeira delas, e talvez a mais importante, é entender porque a comunidade do assentamento Gleba Ribeirão Bonito, que vive no entorno do Parque Estadual Morro do Diabo, não começou o processo de depredação dos recursos naturais que geralmente caracteriza a relação entre assentamentos rurais e as áreas naturais adjacentes $^{1}$. Era de se esperar que, mesmo com uma legislação que garante a integridade da Unidade de Conservação, a comunidade começasse a utilizar os recursos florestais que agora estão mais próximos, já que eles foram assentados na divisa do Parque.

Quando se lembra da proposição de Hardin (1968), o lógico era esperar que a comunidade iniciasse um processo voraz de utilização dos recursos naturais, principalmente madeira para utilização como combustível e para a construção de casas e cerca. Para o problema que Hardin coloca, conhecido como a "tragédia dos comuns", nem sempre a solução de se ter uma terceira parte, geralmente o Estado, controlando a ação da comunidade e impedindo que essa explore os recursos até a sua exaustão, é suficiente, principalmente pelas dificuldades que tal organismo tem de controlar efetivamente as ações ${ }^{2}$.

Pesquisa realizada na mesma região pelo Instituto de Pesquisas Ecológicas (IPÊ) mostrou de forma inequívoca os efeitos que a pressão exercida por um assentamento rural pode causar nos fragmentos florestais. Foram comparados dados de densidade de espécies animais antes e após a implantação de um assentamento

\footnotetext{
${ }^{1}$ Segundo alguns técnicos da Associação Mico-leão-dourado, entrevistados pelo autor em agosto de 2000, um dos principais problemas da Reserva Biológica de Poço das Antas, no Rio de Janeiro, é a depredação causada pelas famílias que foram assentadas no entorno da Reserva.
} 
rural ao lado de um importante fragmento florestal, e os resultados apontam para uma redução significativa da densidade de algumas espécies animais, que são caçadas pelos assentados, além da incidência de fogo nas bordas do fragmento (Cullen Jr., 1997).

Dessa forma, era de se esperar que a relação entre a comunidade do assentamento Gleba Ribeirão Bonito e o Parque Estadual do Morro do Diabo se desse de maneira parecida, ou seja, que a pressão sobre os recursos naturais também fosse grande e levasse a níveis de degradação ambiental elevados. Porém, não é o que se verifica até o momento, o que estimulou a formulação da hipótese do trabalho: a existência de uma estrutura de incentivos, dada pela ação de uma rede de trabalho que envolve organizações ambientalistas não governamentais, organismos estatais de preservação ambiental, cooperativa de assentados e movimento social, está levando as famílias de agricultores assentadas a estabelecer novas formas de relacionamento com a Natureza. Além de não degradar o meio ambiente, essas famílias estão contribuindo, através de projetos articulados por essa rede, para a sua conservação.

Feitas essas considerações sobre o problema de pesquisa e a hipótese central, apresentamos mais algumas observações sobre a região de estudo e sobre uma área específica das ciências naturais que tem grande influência na conformação da realidade estudada.

\footnotetext{
${ }^{2}$ Exemplo claro disto é a ação dos palmiteiros na Mata Atlântica e das madeireiras clandestinas na Amazônia.
} 


\section{2- Fundamentos de Biologia da Conservação e sua aplicação na região do Pontal do Paranapanema}

O Pontal do Paranapanema faz parte da região administrativa de Presidente Prudente, constituída por 20 municípios do extremo oeste do Estado de São Paulo. Inserido entre a confluência dos rios Paraná e Paranapanema, o Pontal está incluído nos limites da Mata Atlântica (Ferrari Leite, 1981; Pádua,1997; Dean, 1996). A cobertura original da região é classificada como Mata Atlântica de Interior ou Estacional Semi-decídua de Planalto, podendo ser considerada uma área de transição para os domínios do Cerrado.

Não faz muito tempo, o Pontal era uma região inteiramente coberta por florestas tropicais de valor biótico singular. Prova disso é que os remanescentes florestais do Pontal abrigam rica e importante biodiversidade, com a presença de inúmeras espécies endêmicas ou ameaçadas de extinção, como o mico-leão-preto (Leontopithecus chrysopygus), a anta (Tapirus terrestris), o macuco (Tinamus solitarius) e a onça pintada (Panthera onca). De fato, as florestas do Pontal eram tão ricas em biodiversidade que em 1942 o então governador Dr. Fernando Costa, com base no Código Florestal de 1934, decretou que grande parte desta região (297.000 ha) fosse transformada em Reserva Florestal e destinada à proteção da flora e fauna.

A fragilidade dos solos, combinada com a concentração de chuvas num período curto do ano e a exposição das encostas, somadas à forma de ocupação desordenada do solo, levou a região a se tornar uma das mais degradadas do estado do ponto de vista ambiental, com predominância do grande latifúndio de pecuária extensiva. No 
decorrer dos anos, o que se verificou foi que a Grande Reserva do Pontal foi perdendo sua área florestada, restando hoje pouco mais de 35.000 ha no Parque Estadual do Morro do Diabo, localizado no município de Teodoro Sampaio e cerca de 12.000 ha em fragmentos de diversos tamanhos espalhados pela região (Valladares-Pádua et alli, 1996).

Essa situação de isolamento dos fragmentos faz com que a manutenção da diversidade biológica de algumas espécies de árvores e animais fique comprometida.

É necessário um número mínimo de indivíduos para garantir a manutenção genética das espécies, que ao longo do tempo vão realizando cruzamentos sucessivos entre os mesmos indivíduos, o que implica em redução da diversidade genética. Dessa forma, para garantir a manutenção da diversidade e da própria existência de espécies é necessária a utilização de uma abordagem que privilegie o conceito de paisagem (Hunter, Jr.,1996; Metzger,1999; Kageyama e Gandara,1993).

Esse conceito da biologia da conservação é cada vez mais utilizado pelas organizações ambientalistas que atuam na região, com destaque especial para o Instituto de Pesquisas Ecológicas, que há mais de 12 anos vem se dedicando à conservação de espécies ameaçadas de extinção da região. Para que os esforços em prol da conservação de espécies como a anta ou a onça dêem resultados, apenas a manutenção dos fragmentos que restaram ou do próprio Parque do Morro do Diabo é insuficiente, pois não garante o fluxo genético. Se torna necessária então a implantação de corredores florestais que possam contribuir para o fluxo dos genes, minimizando o isolamento a que foram submetidas as espécies animais e vegetais. Além disso, garantir a integridade dos fragmentos que ainda existem é também muito importante, principalmente o Parque do Morro do Diabo, pois nele estão essas 
últimas "sementes de biodiversidade" da região (Cullen Jr. e Valladares-Pádua, 1999). Uma das formas de garantir a integridade destas áreas é protegendo-as dos impactos externos advindos da ação humana, como o fogo, a retirada de madeira e a caça, o que pode ser conseguido através da implantação de "zonas de amortecimento" (buffer zone) (Hunter,JR., 1996).

Estas duas estratégias (corredores biológicos e zonas de amortecimento) foram implantadas no assentamento Gleba Ribeirão Bonito, com a participação das famílias assentadas. Como já foi dito, os assentados, além de não invadirem a área do Parque para extrair recursos naturais do mesmo, ainda estão colaborando com a conservação da natureza, participando ativamente da implantação destas estratégias, uma vez que tanto a zona de amortecimento quanto o corredor biológico estão sendo implantados em áreas do assentamento. Para a zona de amortecimento, os assentados que fazem divisa com o Parque disponibilizaram uma faixa de aproximadamente 50 metros de largura para a implantação de plantios consorciados de espécies florestais nativas e exóticas. Para o corredor, as famílias concordaram em destinar uma área (que poderia ter sido destinada a um lote) para a implantação do corredor, que vai ligar o Parque a um fragmento florestal do assentamento.

Ora, é de se estranhar que essas famílias concordem em destinar uma parte do seu lote para tais fins, ainda mais quando se leva em conta o pequeno tamanho dos mesmos (algo em torno de 20 ha). Alem disso, são os próprios assentados que implantam os sistemas agroflorestais nas áreas, num esforço coletivo que é intrigante, tanto do ponto de vista prático quanto do ponto de vista teórico, como veremos adiante. 


\section{3 - A construção social da questão ambiental no Pontal do Paranapanema}

Após essa breve exposição sobre alguns conceitos da biologia da conservação, voltamos ao questionamento principal do trabalho. Porque as famílias do assentamento Gleba Ribeirão Bonito estão agindo desta maneira, ajudando a conservar a natureza? A hipótese, já apresentada neste texto, aponta para uma certa estrutura de incentivos dada pela ação de uma rede. Mas, que rede é essa afinal?

Para encaminhar as primeiras repostas, se faz necessária uma breve apresentação dos principais atores sociais que estão envolvidos com a temática ambiental na região, e que acabam compondo uma verdadeira rede de trabalho.

Como já foi exposto, a região do Pontal do Paranapanema configurou-se, ao longo da última metade do século $\mathrm{XX}$, como uma das mais degradadas do estado do ponto de vista ambiental. Tal situação se agravou com a construção de usinas hidrelétricas no rio Paranapanema, sendo que a última barragem, em Rosana, em meados da década de 80, acabou por inundar parte do Parque do Morro do Diabo. Pouco antes, havia sido descoberto na região um minúsculo primata considerado extinto pelos pesquisadores, o mico-leão-preto. Quando da inundação do Parque pela barragem de Rosana, foram mobilizados grandes esforços para garantir a conservação desta espécie, dada a sua raridade e fragilidade. Nessa época, portanto, a população da região passa a tomar contato com um tema que seria considerado dos mais importantes alguns anos depois, a conservação da biodiversidade. Tomando uma perspectiva construtivista para a análise, pode-se afirmar que é a partir daí que começa a se configurar na região uma questão ambiental, pois os problemas 
ambientais só passam a existir a partir do momento que determinado grupo social passa a encarar determinadas situações como situações de risco, como problemas (Hanningan, 1995; Berger e Luckmann, 1999). Hanningan (1995), citando o trabalho de Best (1989), sugere três fases para o estudo dos problemas ambientais numa perspectiva construtivista: os problemas em si, os elaboradores dos problemas e o processo de elaboração dos problemas.

Existem certas questões chave que devem ser consideradas quando se analisa o conteúdo de um problema: qual é a essência do problema? Como o problema é tipificado? Qual é a retórica utilizada pelos formuladores do problema e como eles apresentam esse problema para persuadir as suas audiências?

Para o nosso estudo, é fácil distinguir os formuladores dos problemas ambientais na região do Pontal do Paranapanema, uma vez que são os cientistas, ligados à Companhia Energética de São Paulo (CESP), universidades e organizações ambientalistas, que dão o alarme para o problema da conservação da biodiversidade na região. Obviamente, esse problema está ligado a outros, como o assoreamento dos rios e a perda de ertilidade dos solos, mas ele assume um papel mobilizador que irá influenciar significativamente a percepção da população sobre as questões ambientais.

Quando se trata de identificar os recursos retóricos utilizados pelos formuladores dos problemas ambientais, são sugeridas três categorias básicas: a primeira são os dados coletados a respeito de determinada situação, que seriam as definições, os exemplos e as estimativas numéricas; a segunda são as justificativas que definem que determinada situação necessita ser combatida; e a terceira são as conclusões a que se chega, o que vai determinar as atitudes que devem ser tomadas para minimizar ou 
eliminar determinada situação. Pode-se perceber que a essência destas ações é claramente dominada pelos formuladores dos problemas, na maioria das vezes com base em conhecimentos científicos.

Latour (2000), em importante trabalho sobre a forma como a ciência se desenvolve, também aponta para essa direção. Para ele, os cientistas representam os seus objetos de estudo, falando por eles quando têm que exercer o seu papel de negociador. A ciência, portanto, se organiza em cinco horizontes fundamentais: a) mobilização do mundo, através de instrumentos, expedições, coleções e enquetes. O pesquisador deve fazer seu objeto de estudo "falar", de maneira que possa representá-lo; b) autonomização da pesquisa que ocorre com a "criação de colegas", de instituições, profissões, etc.; c) mobilização da inteligência estratégica, onde aparecem então as alianças que os pesquisadores estabelecem com outros segmentos da sociedade; d) encenação, que são as relações públicas que o pesquisador estabelece com seus aliados, com seus clientes (a expressão encenação não deve ser entendida como algo pejorativo ou que diminua o pesquisador, ao contrário, é tão importante quanto as outras); e) os laços e ligações, onde os conceitos e as teorias têm um papel fundamental na articulação dos quatro horizontes anteriores.

No caso do Pontal do Paranapanema, os cientistas conseguiram colocar em pauta e transformar num problema ambiental a questão da conservação da biodiversidade. São eles que falam em nome da natureza, que negociam com os outros segmentos da sociedade o destino da natureza ${ }^{3}$, e se utilizam principalmente do aparato e do reconhecimento próprios da atividade científica.

\footnotetext{
${ }^{3}$ Para Latour, isso implica em reconhecer que a separação entre sociedade e natureza não passa de um mito. Talvez a maior confirmação do que diz Latour esteja no fato de que os cientistas, neste caso, só
} 
Dentre esses cientistas, um grupo se destacou ao longo do tempo por sua atuação constante na região. Agrupados em uma organização não governamental, os cientistas do Instituto de Pesquisas Ecológicas (IPÊ) aparecem regionalmente como os representantes da natureza no Pontal do Paranapanema, principalmente para as famílias assentadas.

Essa legitimidade para representar a natureza facilitou para esse grupo de cientistas o estabelecimento de um diálogo, que se mostrou de importância fundamental para o sucesso dos esforços de conservação na região, com as lideranças do Movimento dos Trabalhadores Rurais Sem Terra (MST), importante ator social que atua na região.

Como já foi apresentado no início do texto, uma pesquisa levada a cabo pela equipe do IPÊ, coordenada pelo engenheiro florestal Laury Cullen Júnior, apontou as consequiências desastrosas, do ponto de vista ambiental, da implantação dos assentamentos rurais próximos aos fragmentos florestais. Acontece que as áreas passíveis de desapropriação na região são, em geral, grandes latifúndios de terra ocupados de forma irregular. São também as áreas onde se encontram os maiores e mais importantes fragmentos, conforme apresentamos no capítulo 2. Consequentemente, os fragmentos terão, em grande parte, assentamentos no seu entorno. Essa situação, observada do prisma da conservação ambiental, se configurava como potencialmente danosa, e os cientistas, representando a natureza, passaram a negociar com as lideranças dos assentados e com o Estado, através do

puderam "representar" a natureza quando convocaram para esta finalidade outros atores sociais e sobretudo atores leigos, os agricultores. O mito a que se refere Latour está em dizer que sociedade e natureza são separados e que quem representa a sociedade de forma correta é a ciência, são os cientistas que ensinam para as pessoas como a sociedade é. Este caso mostra que sem a rede de atores variados, a própria ação dos cientistas seria esvaziada. 
Instituto de Terras do Estado de São Paulo (ITESP), formas de conciliar a presença humana e suas atividades produtivas com a manutenção da natureza.

No início deste processo de negociação, contudo, o caminho escolhido pelos ambientalistas indicava a necessidade de isolar os fragmentos florestais, afastando os assentamentos do seu entorno. A solução proposta, segundo este caminho, era bem pragmática: estabelecer uma distância mínima entre assentamentos rurais e fragmentos florestais, garantindo uma faixa contínua ao redor dos mesmos que mantivesse afastados os assentados. Essas faixas despovoadas seriam destinadas a projetos de preservação. Tal proposta chegou mesmo a ser feita quando do assentamento definitivo da Gleba Ribeirão Bonito. Como era o primeiro assentamento que seria implantado no entorno do Parque Estadual do Morro do Diabo, a idéia dos ambientalistas, explicitada em reuniões com a diretoria do ITESP, era destinar a área do entorno do Parque para a preservação ambiental. Tânia Andrade, então Diretora deste Instituto, falando sobre uma das primeiras reuniões com a equipe do IPÊ, relata o seguinte: “...eles queriam destinar toda a área do entorno do Parque para preservação ambiental, o que era impossível de negociar com as famílias que seriam assentadas. Isso implicava em reduzir o número de famílias...em determinado momento, eles disseram que não sabiam trabalhar com as pessoas, ao que respondi: ah, é mais fácil fazer assembléia com onças do que assembléia com assentados". O depoimento de um dos pesquisadores também reforça a idéia de que no início os ambientalistas viam os assentados como grande ameaça à natureza na região: “...no início do movimento, me senti fortemente assustado, pois a chegada dos assentados parecia uma grande ameaça à conservação. (Entrevista de Laury Cullen Júnior para o site Ambiente Brasil - 
www.ambientebrasil.com.br).

Percebendo que o primeiro caminho (tirar os assentados de perto dos fragmentos e do Parque) seria totalmente inviável, os ambientalistas tiveram necessariamente que trilhar um caminho alternativo que apontava para a necessidade de integrar as famílias assentadas ao processo de conservação ambiental na região.

Assim, teve início um intenso diálogo entre a direção do MST, representando o grupo de famílias que demandava um pedaço de terra e condições melhores de vida, e os cientistas do IPE, representando a natureza, para empregar a terminologia de Bruno Latour. É destes diálogos que se forma e se consolida a rede de trabalho que está influenciando as práticas das famílias assentadas. Nessa rede também foram incorporados outros segmentos e organismos, como a direção do Parque Estadual do Morro do Diabo, do Instituto Florestal do estado de São Paulo, a Escola Superior de Agricultura "Luiz de Queiroz" da USP, a Associação Mata Ciliar, organização não governamental ambientalista, e diversos parceiros nacionais e internacionais que apoiam financeiramente as iniciativas e projetos da rede. Podemos afirmar que o IPE mobiliza a inteligência estratégica, para falar como Latour, o que possibilita que os projetos possam acontecer. É nesse sentido que Latour compara a atividade científica com o capitalismo financeiro. $\mathrm{O}$ cientista consegue mobilizar recursos, com os quais, através do seu trabalho e esforço, gera uma quantidade de dados que vão render-lhe reconhecimento, que por sua vez vai gerar mais recursos para novos projetos e pesquisas, num círculo virtuoso que se estende ao longo do tempo ${ }^{4}$.

\footnotetext{
${ }^{4}$ Uma boa ilustração desta idéia aconteceu no mês de março de 2002, quando o Whitley Gold Award, um dos principais prêmios de conservação ambiental, foi atribuído ao pesquisador do IPÊ, Laury Cullen Júnior, pelos trabalhos desenvolvidos no Pontal do Paranapanema. Esse reconhecimento mundial vai gerar novos recursos para novos projetos, que vão gerar novos resultados, e assim por diante.
} 
A existência desta rede, envolvendo diferentes organizações, atores e objetos, é a responsável por influenciar a ação das famílias assentadas, através do fornecimento de uma determinada estrutura de incentivos, que será detalhada mais adiante. Por hora, devemos dizer apenas que essa rede tem como objetivo principal promover a conservação da natureza, por um lado, e contribuir para a melhoria da qualidade de vida das famílias assentadas, por outro.

Percebe-se, também, que esses diferentes nós da rede influenciam-se mutuamente. Assim, nenhuma das organizações permanece a mesma após a interação com as outras. Os cientistas ambientalistas, antes apenas preocupados com a manutenção da diversidade biológica, passam a se preocupar também com as comunidades assentadas, enquanto que as lideranças do movimento social deixam de encarar a conservação da natureza como um "luxo de país rico".

$\mathrm{Na}$ entrevista citada anteriormente pode-se perceber como muda a orientação do sentido da ação dos ambientalistas: "No decorrer desses últimos anos, tenho sentido que esta é a real missão de minha vida: a junção de conservação com a melhoria e a esperança de uma vida melhor para populações menos favorecidas, como a dos assentados.

Minha principal luta tem sido a implementação de uma cultura agroecológica na interface entre assentamentos rurais e os fragmentos florestais da Mata Atlântica, e portanto, a conservação de ecossistemas de forma integrada com o avanço da reforma agrária na região" (Entrevista ao site Ambiente Brasil www.ambeintebrasil.com.br)

Outra organização importante que atua na região, citada anteriormente, é a Fundação Instituto de Terras do Estado de São Paulo (ITESP), ligada à Secretaria 
Estadual de Justiça e Defesa da Cidadania. Esse organismo é o responsável pela política agrária estadual e, através de convênio com o INCRA (Ins tituto Nacional de Colonização e Reforma Agrária), responsável pela maioria dos assentamentos da região do Pontal. O ITESP lançou, em julho de 1998, o Programa Pontal Verde (ITESP, 1998), com o objetivo de recuperar as áreas de reserva florestal legal e de preservação permanente dos assentamentos que estão sob a sua responsabilidade. Com o apoio da ESALQ/USP, desenvolveu um plano de recuperação ambiental que está em andamento desde então, o que reforça a idéia de que, nos últimos anos, a região passou a entender como importante a questão ambiental.

Contudo, essa é uma organização que encontra uma certa dificuldade de se incorporar efetivamente na rede de trabalho composta pelas organizações citadas anteriormente, o que faz com que, em muitos momentos, aconteça uma sobreposição excessiva de ação nos assentamentos. Aliás, é essa sobreposição que faz com que a dificuldade de articulação do ITESP com as outras organizações fique cada vez mais intensa, como será demonstrado adiante. 


\section{4- SOBRE OS MÉTODOS DE INVESTIGAÇÃO}

Para o levantamento das informações foram utilizadas entrevistas com as famílias assentadas, entrevistas com os técnicos e militantes das organizações que atuam na região, visitas aos lotes das famílias e coleta e análise de materiais produzidos pelas organizações que atuam na região. As entrevistas foram conduzidas de forma semi-estruturada, estimulando, sempre que possível, o entrevistado a expor a sua visão dos assuntos que estavam sendo discutidos. Foram entrevistados técnicos do Instituto de Pesquisas Ecológicas (IPÊ), do Instituto de Terras do Estado de São Paulo (ITESP), guardas florestais do Instituto Florestal da Secretaria de Meio Ambiente do Estado de São Paulo (IF/SMA) que atuam no Parque Estadual do Morro do Diabo (PEMD), militantes do Movimento dos Trabalhadores Rurais Sem Terra (MST), técnicos da Cooperativa de Comercialização e Prestação de Serviços dos Assentados de Reforma Agrária do Pontal do Paranapanema (COCAMP), técnicos da Universidade de São Paulo ligados aos projetos ambientais na região, além de 27 famílias do assentamento Gleba Ribeirão Bonito que têm seus lotes ao longo da divisa do assentamento com o Parque Estadual do Morro do Diabo (20 famílias) ou são vizinhas do fragmento florestal que compõe, com outros fragmentos, a Reserva Florestal Legal do assentamento ( 7 famílias). Essas famílias foram acompanhadas através de visitas aos lotes durante o período de 24 meses, nos quais o pesquisador percorria, com as famílias assentadas, os lotes rurais. Essa técnica de investigação fez com que a maioria dos dados obtidos tivessem caráter muito mais qualitativo do que quantitativo. Nessas visitas aos lotes, percorrendo o campo e 
observando as transformações que foram ocorrendo no ambiente físico e no discurso das famílias, foi possível apreender aspectos que entrevistas formais não conseguiriam apontar. Muitas vezes as conversas à sombra de uma árvore estimularam que membros da família que nunca haviam respondido perguntas nas entrevistas formais se expressassem de forma mais autêntica, em especial as mulheres. O ambiente informal de conversa, o "café com bolinho de chuva", mostrou-se um espaço adequado para o diálogo entre pesquisador e as famílias assentadas.

As visitas, muitas vezes também, foram feitas através do acompanhamento de outros assentados nos lotes dos vizinhos. Essa estratégia teve como objetivo estimular e acompanhar a discussão entre os vizinhos, verificar as diferenças de manejo em cada lote e fomentar a percepção de que cada um deles é parte de um esforço mais amplo de transformação da realidade, ou seja, que as ações de cada um estão inseridas em um contexto mais amplo e que influenciam a tomada de decisão dos outros. Assim, muitas vezes tivemos três ou quatro pessoas percorrendo os lotes, verificando a evolução dos sistemas agroflorestais implantados e conversando a respeito das atividades que estavam sendo desenvolvidas no assentamento e na região.

Também algumas das visitas foram acompanhadas pelos técnicos da Cocamp e do IPE. Nesta fase da pesquisa, os técnicos da Cocamp estavam com sérias dificuldades de deslocamento para os assentamentos, e então foram convidados a participarem das visitas de campo. Essa "ida ao campo" junto com os técnicos da Cocamp contribuiu para que o pesquisador verificasse e compreendesse melhor as relações entre estes técnicos e as famílias assentadas, sua influência na construção do 
discurso dessas famílias e nas transformações das práticas de manejo do lote. As "idas ao campo" com os técnicos do IPÊ também foram muito interessantes do ponto de vista da investigação. Foi possível captar momentos únicos de negociação entre técnicos e as famílias assentadas, em especial com relação ao tipo de espécies que seriam plantadas nos sistemas agroflorestais. Muitas vezes, também, foram feitas visitas, acompanhando os técnicos do IPÊ, em outros assentamentos, o que foi importante para que se pudesse perceber os diferente contornos que assumem as negociações entre os atores.

Além das entrevistas e visitas, o pesquisador participou de 3 encontros realizados na sede do Parque Estadual do Morro do Diabo que tiveram por objetivo estimular a troca de experiências entre as famílias sobre as práticas agroflorestais que vêm desenvolvendo. Esses encontros foram importantes já que proporcionaram ao pesquisador o contato informal com a realidade que essas famílias vêm enfrentado, tanto nos aspectos técnicos de condução dos sistemas que implantaram quanto naqueles relacionados aos aspectos organizativos das atividades desenvolvidas. Mais uma vez, o problema (ou a questão) da ação coletiva assumiu, nestes encontros, um papel preponderante, o que mostrou a fertilidade do horizonte teórico representado pela economia das instituições, como será apresentado adiante.

A orientação metodológica que fundamentou a pesquisa de campo, portanto, circunscreve-se no campo da pesquisa participante.

Dado o envolvimento prévio do pesquisador com os sujeitos da pesquisa, tanto com as famílias assentadas quanto com os técnicos das organizações, em muitos momentos foi difícil manter o distanciamento entre pesquisador e sujeitos da pesquisa, o que foi considerado, para os objetivos propostos, muito interessante, uma 
vez que a possibilidade de participar ativamente das atividades que estão sendo desenvolvidas na região fez com que a análise pudesse atingir um grau elevado de aprofundamento.

Enfim, a participação ativa do pesquisador nas atividades desenvolvidas na região pela rede de organizações facilitou a compreensão das diferentes arenas onde se dão as negociações entre os diferentes atores envolvidos com a questão socioambiental na região. É nessas arenas que são negociados e definidos os limites e o alcance das ações dos diferentes atores sociais. 


\section{5 - AÇÃO COLETIVA E INSTITUIÇÕES NO PONTAL DO PARANAPANEMA}

Após a apresentação do processo de construção da questão ambiental no Pontal do Paranapanema e da formação de uma rede de organizações preocupadas com a mesma, podemos voltar à questão principal do projeto de pesquisa. Relembrando, estamos interessados em entender porque as famílias se engajaram em uma atividade coletiva que busca contribuir para a conservação da natureza. Esta situação encerra dois paradoxos: i) a constatação de que as famílias assentadas e as organizações conseguem coordenar as suas ações individuais de forma a promover a ação coletiva e ii) o fato desta ação coletiva ser a conservação da natureza.

O campo teórico contemporâneo que mais auxilia na abordagem deste tema é o da nova economia institucional, que lida diretamente com o problema da ação coletiva. O interessante, contudo, é a convergência entre os resultados da economia das instituições e os alcançados pelas escolas sociológicas trabalhando com a construção de redes, conforme apresentado no capítulo 4.

Olson (1965) refuta alguns pressupostos recorrentes sobre a ação coletiva, em especial o que postula que grupos de indivíduos com interesses comuns logicamente coordenariam suas ações de forma a realizar tais interesses. Para ele, essa condição não é suficiente para a efetivação da ação, e um dos principais motivos é a ocorrência de um tipo de comportamento conhecido como "carona" (free-rider, no original). A análise do comportamento das organizações, para ele, deve se iniciar pela investigação dos seus propósitos. Mesmo existindo vários tipos de organização, elas 
têm em comum o objetivo de promover o interesse comum dos seus membros, ou seja, os indivíduos se agregam em uma entidade supra-individual que tem por objetivo promover o interesse coletivo.

Porém, alguns problemas relevantes devem ser destacados, segundo Olson. O primeiro deles é a contradição entre interesses individuais e interesses coletivos. Um bom exemplo disso é o caso das firmas de um determinado setor industrial. Quando todas as firmas tentam maximizar seus lucros, o lucro total da indústria será menor, porque o preço cai e, sendo a demanda inelástica, a receita também cai. Como cada firma espera que as outras reduzam suas produções para que o preço suba, e como todas são suficientemente pequenas para não serem notadas pelo grupo todo, o que estimula um comportamento do tipo carona, o resultado coletivo é que o preço continuará caindo, pois racionalmente cada firma espera maximizar suas vendas. Não se poderia esperar outra atitude das firmas em tal situação, pois se diminuíssem a sua produção, individualmente, o preço continuaria caindo e ela teria menos produto para vender, diminuindo ainda mais o lucro individual.

Assim, conclui o autor, o comportamento racional individual pode não ser benéfico do ponto de vista coletivo, ainda que seja o mais adequado para cada membro do grupo. A única forma de impedir a queda continuada do preço é uma intervenção externa, por exemplo através do Governo, de uma política de preços mínimos ou ainda de um acordo de cartel. Essa conclusão, contudo, leva à constatação de que a coordenação da ação coletiva tem um custo, seja o de pressionar o Governo, seja o de garantir mecanismos que incentivem ações cooperativas entre as firmas. 
Dessa forma, cabe a pergunta: em que situações o benefício coletivo seria alcançado, e qual a quantidade máxima do bem coletivo será produzida?

Para Olson, a produção do bem coletivo depende do custo que alguém do grupo está disposto a pagar para que o bem seja produzido. Se a relação custo/benefício for extremamente atraente para pelo menos um indivíduo do grupo, ou seja, se pelo menos um indivíduo do grupo arcar com os custos de produção do bem coletivo, então o bem será produzido. Tal produção depende ainda da fração do ganho total de um bem público que é auferida por um indivíduo do grupo, do ganho total, que depende do nível de produção do bem e do tamanho do grupo, que depende, por sua vez, não apenas do número de participantes, mas do valor que cada participante atribui ao bem coletivo, e ainda do custo individual da participação.

Propondo uma análise da ação coletiva que leva em consideração o tamanho do grupo, Olson demonstra que nos grupos grandes a tendência é que os indivíduos adotem o comportamento do tipo "carona", principalmente quando o bem coletivo é não excludente, ou seja, se o bem for produzido todos os participantes do grupo têm acesso a ele.

Tal teoria da ação coletiva leva a uma visão extremamente negativa sobre as possibilidades de cooperação entre os indivíduos. Isso não quer dizer, contudo, que ela não admita a existência de comportamento altruísta, apenas esse é um tipo de comportamento não relevante para a análise. De qualquer forma, apesar destas restrições apresentadas pelo autor, o fato é que a cooperação entre os indivíduos ocorre, diversos tipo de ação coletiva acontecem, produzindo por sua vez bens coletivos, em alguns casos em níveis ótimos. A realidade parece destruir o mito neoclássico segundo o qual a sociedade é um conjunto de indivíduos isolados que, 
quando colocados em situações coletivas, tendem sempre a apresentar comportamentos oportunistas.

No caso das famílias assentadas na Gleba Ribeirão Bonito, era de se esperar que, ao serem colocadas frente a uma situação na qual elas poderiam se apropriar individualmente dos recursos naturais do parque, como a madeira, por exemplo, elas apresentassem um comportamento do tipo oportunista. O impacto ambiental de uma família que retira um pouco de madeira de uma área de mais de 35.000 ha seria muito pequeno, o que deveria levar logicamente a um tipo de ação predatória por parte de todas as famílias. Porém, não é o que vem ocorrendo.

Coleman (1990) também tratando desta questão, apresenta os fundamentos de uma teoria social com base no individualismo metodológico. Como se estruturam as relações sociais? Qual é a lógica através da qual os indivíduos coordenam as suas ações de forma que se tornem sistêmicas? Quais os principais elementos que devem ser incorporados a uma teoria da ação social? Estas parecem ter sido as principais questões que nortearam o trabalho do autor.

Iniciando por três pontos principais da teoria para explicar o comportamento dos sistemas sociais: a) os efeitos das propriedades dos sistemas na ação individual; b) a ação dos atores que estão no sistema; e c) a combinação ou interação destas ações, originando a ação sistêmica, o autor sustenta que a análise tem lugar no nível do ator individual, e o nível sistêmico existe apenas como uma propriedade emergente que caracteriza o sistema de ação como um todo. Todavia, segundo Coleman, resultarão propriedades do nível sistêmico, e algumas proposições serão geradas neste nível. 
Os principais elementos da teoria são: os "atores" (actors) e as "coisas" (things). Essas "coisas" podem ser divididas em "recursos" e "eventos". Entre os atores e as coisas, existem dos tipos possíveis de relação: "controle" e "interesse". Os atores teriam controle sobre recursos próprios e, ao mesmo tempo, podem ter interesse em recursos sobre os quais não têm controle. Para o entendimento do comportamento dos sistemas sociais esses elementos e formas de interdependência entre eles são fundamentais.

Para Coleman, o interesse tem um papel central. Se os atores controlassem todos os recursos que os interessam, então eles teriam apenas que exercer o seu controle de forma a satisfazer seus interesses. Porém, os atores não estão plenamente no controle das atividades (ou recursos) que podem satisfazer seus interesses, mas procuram controlar aquelas atividades que estão parcialmente ou totalmente no controle de outros atores ${ }^{5}$. Esse é, segundo Coleman, um fato estrutural que diferencia um sistema social de um grupo (set) de indivíduos que independentemente exercem controle sobre aquelas atividades que satisfazem seu interesse.

Feitas essas considerações, o autor apresenta então três tipos de formas de interdependência, baseando-se nos trabalhos de Friedman (1971):

a) Interdependência Estrutural: é aquela em que cada ator assume que as ações do outro são independentes das suas. Aqui, segundo o autor, a racionalidade é bem definida e o ambiente é tido como fixo. É forma de interdependência mais importante para o desenvolvimento da teoria.

\footnotetext{
5 No caso em estudo, as famílias assentadas têm o controle sobre o seu lote, enquanto que os ambientalistas têm interesse em que os primeiros transfiram parte do controle sobre o lote para eles, para que novas formas de utilização, mais próximas aos seus interesses sejam implantadas. Esse é um ponto fundamental para o nosso estudo, uma vez que se inicia aí um processo de interação social que anteriormente não existia, e que é de suma importância para a análise.
} 
b) Interdependência Comportamental: quando as ações do ator levam em consideração as ações dos outros atores. Cada ação é baseada em considerações mais complexas. A questão do que é racional para o ator depende do número e do caráter das escolhas futuras e também do tipo de estratégias que serão usadas pelos outros atores.

c) Interdependência Evolucionária: as relações do tipo comportamental se dão ao longo de grandes períodos de tempo. Passam a atuar, então, alguns mecanismos de seleção, que podem levar a equilíbrios estáveis.

Também importante para a análise são os tipos possíveis de ação disponíveis para o ator que, segundo classificação de Coleman, são bastante limitados:

a) dos atores para seus próprios recursos (que já controlam): não envolve outros atores, portanto é socialmente irrelevante;

b) quando um ator tenta obter controle de um recurso que é de seu interesse, abrindo mão do controle de um outro recurso sobre o qual tem controle. Esse tipo de ação é a transação, e o objetivo do ator que se envolve em tal tipo de ação é ampliar a realização de seus interesses ${ }^{6}$;

c) transferência unilateral: o controle é obtido sem que haja um envolvimento de recursos próprios do ator. $\mathrm{O}$ ator transfere, por vontade própria, seus direitos para outro ator, na expectativa de, com essa ação, auferir melhores resultados e satisfazer assim seus interesses.

É necessário entender que os recursos não são apenas bens e serviços, mas são entendidos aqui de uma forma mais ampla, incluindo o direito de alienação ou

\footnotetext{
6 Para os ambientalistas, numa transação com as famílias assentadas, a maximização dos seus interesses está relacionada à conservação ambiental, enquanto que os assentados também esperam, com essa transação, maximizar os seus retornos, inclusive os financeiros.
} 
controle da ação dos outros, ou aqueles bens e eventos que influenciam a determinação do resultado sobre os quais outros atores tenham interesse.

Após a apresentação dos tipos de ação disponíveis para o ator, são apresentadas as estruturas de ação social que podem ser encontradas na sociedade. Os diferentes tipos de estrutura de ação dependem:

a) dos recursos envolvidos;

b) dos tipos de ação que se dão;

c) dos contextos em que as ações ocorrem.

O autor apresenta um mapeamento dos tipos de estruturas de ação, que vai balizar todo o desenvolvimento do livro. Para nós, basta dizer que serão tratadas prioritariamente aquelas ações consideradas propositais. Destas, destacamos aquelas ações que transferem direitos sobre os recursos ou direitos de controle sobre os recursos e aquelas ações que têm efeitos sobre muitos. Nas primeiras, três tipos são relevantes: a) transferências unilaterais ou transações; b) ações que transferem o direito de controlar ações ou aquelas onde esses direitos são transferidos; e c) transferências que ocorrem em algum tipo de sistema de relações ${ }^{7}$. Dentre as ações que têm efeitos sobre muitos, encontram-se aquelas que provocam ou apresentam externalidades, abrangendo fenômenos sociais mais amplos do que os estritamente econômicos.

Outro conceito importante é o de equilíbrio social, segundo o qual, através de trocas sociais, há uma redução das disparidades entre interesse e controle, até um ponto de equilíbrio onde não existirão mas as trocas, uma vez que as expectativas de todos os atores em ver realizados os seus interesses estariam satisfeitas. Neste ponto,

\footnotetext{
7 Este é um conceito importante na teoria de Coleman, e corresponde a um conceito ampliado de mercado. O mercado é um sistema de relações importante, porém tais sistemas não se resumem a ele.
} 
portanto, cada ator teria maximizado sua expectativa de realização de interesse até o grau permitido pelos recursos com os quais começou. A comparação interpessoal de utilidade (interesse) por uma métrica única é descartada, sendo que a medida relevante de interesse é aquela elaborada pelo próprio ator.

Este equilíbrio social pode ser um ótimo. Isso não implica, contudo, que qualquer equilíbrio será um ótimo. Casos em que as ações tem efeitos sobre muitos (externalidades) podem levar a equilíbrios não ótimos.

Ao abordar as relações entre os atores, Coleman sugere uma classificação importante para a sua teoria. Para ele, as relações podem ser de dois tipos: simples e complexas. As primeiras poderiam ser chamadas também de relações autosustentáveis, já que os estímulos para que as partes continuem se relacionando são dados pela própria relação, de forma intrínseca ${ }^{8}$.

As relações complexas, por sua vez, são não sustentáveis, porque dependem de uma terceira parte para a sua continuidade. Os incentivos para que as partes continuem na relação não são intrínsecos a ela e têm que ser supridos de fora. É o tipo de relação onde as organizações formais são constituídas, e o tipo de organização precisa ser construído, porque é baseado em estruturas de incentivos mais complexas, envolvendo três ou mais partes para cada relação de dois atores. A organização é uma estrutura de relações feita a partir de obrigações e expectativas, mas aqui isto não é requerido, como é na organização social composta de relações simples, em que cada obrigação ou expectativa pessoal influencia o balanço individual que cada ator faz da relação.

${ }^{8}$ Um exemplo seriam as relações de amizade, ou os laços familiares. 
As relações simples seriam, então, naturais, enquanto que as complexas seriam relações artificiais.

Entre as relações, é importante destacar as relações de autoridade que se estabelecem entre os atores. Essas relações acontecem quando há a transferência de direitos de controle sobre recursos fora de um sistema de relações (como por exemplo o mercado), podendo ser unilateral ou com ressarcimento dentro de uma troca.

Como já foi dito, entre os recursos que os atores controlam, estão os direitos ${ }^{9}$. Entre estes, dois são fundamentalmente importantes: o direito de controlar a própria ação e o direito de transferir o direito de controle da própria ação para outro ator.

As relações de autoridade podem ser de dois tipos: disjuntas e conjuntas. As relações do primeiro tipo (disjuntas), numa simplificação, seriam aquelas onde a aceitação da autoridade não implica em benefícios para o subordinado, só se realizando mediante uma compensação. É uma relação que se realiza através da troca. Um exemplo é o do empregado de uma firma, que se engaja em uma relação de autoridade como subordinado no intuito único de obter um salário.

Já nas relações de autoridade conjuntas, a aceitação da autoridade pelo subordinado é acompanhada por um benefício explícito, o que permite que ocorra mediante uma transferência unilateral. Existe um alinhamento de interesses entre o subordinado e o líder, de forma que o interesse do subordinado se realiza nas ações do líder.

O autor mostra que a ação dos indivíduos não ocorre sempre em ambientes competitivos, como os mercados, mas os indivíduos agem muitas vezes sob a

\footnotetext{
9 Recursos para Coleman é um conceito amplo, envolvendo aspectos outros que os puramente econômicos.
} 
autoridade de outros, ou seja, as estruturas sociais envolvem organizações e grupos de pessoas, que se engajam em entidades supra-individuais, como as nações, a família e as associações. Vistas de fora, essas entidades podem ser entendidas como agrupamentos de atores individuais, porém, vistas de dentro, elas podem ser caracterizadas como estruturas de autoridade ${ }^{10}$.

As diferenças entre relações de autoridade conjuntas e disjuntas são importantes não apenas porque correspondem às diferentes formas de autoridade encontradas, mas também porque vão levar a diferentes tipos de comportamento e de problemas.

Nas relações disjuntas, como existe um benefício externo, é fácil entender porque as pessoas se engajam na relação e transferem para outra o direito de controlar suas ações $^{11}$.

Para as relações conjuntas, em que esse benefício externo não existe, isso se torna uma tarefa um pouco mais complicada.

Em alguns casos, como no exemplo utilizado pelo autor, em que um indivíduo está perdido e transfere para outro que sabe o caminho o direito de controlar a sua ação, guiando a ambos, fica evidente o benefício para aquele que se engaja na relação subordinando a sua ação à decisão do outro indivíduo. Isso vai acontecer ( a transferência de controle da ação) porque o indivíduo está confuso e desorientado, porque o ambiente está confuso e desordenado ou porque o outro indivíduo tem qualidades que fazem com que o primeiro transfira o controle para ele ${ }^{12}$.

Os principais problemas que aparecem nas relações de autoridade também são diferenciados. Nas relações conjuntas, o principal problema é o aparecimento de

\footnotetext{
${ }^{10}$ Esse ponto é muito importante para a compreensão das formas que assume a ação coletiva.

${ }^{11}$ Por exemplo, o empregado que entrega o controle da sua ação ao patrão em troca do salário.
} 
comportamentos do tipo "carona" (free-rider). Para minimizar ou suplantar tal problema, seria necessário o estabelecimento de normas que apoiassem o interesse comum $^{13}$. Outro problema importante e, segundo o autor, pouco explorado, se dá quando os indivíduos passam a transferir quantidades cada vez maiores dos seus direitos para uma autoridade central.

Ainda para as relações conjuntas, um problema que pode ocorrer é que o líder se desvie dos interesses dos subordinados, passando a atuar cada vez mais no sentido de atender aos seus próprios interesses.

Já nas relações disjuntas, o principal problema é que os resultados das ações dependem em parte dos atores subordinados, que não têm interesse intrínseco nos resultados, além de terem interesses próprios mesmo depois da transferência do controle de suas ações. Os resultados de uma empresa dependem dos seus funcionários. Estes, porém, estão interessados apenas no salário, que é a compensação pela transferência do controle de sua ação. É necessário, portanto, que exista uma estrutura de incentivos que minimize tal problema. A participação nos lucros da empresa, cada vez mais comum no meio empresarial, parece ir neste sentido.

Um problema comum aos dois tipos de relação é que o líder pode, utilizando-se de tal condição, querer ampliar o seu controle sobre os subordinados, buscando controlar ações que não foram transferidas no início da relação.

Já as limitações de autoridade podem se dar de duas formas: organização (ou ordem construída), que surge com algum propósito definido, ou de ordem espontânea, forma que surge da contínua relação entre os atores.

\footnotetext{
${ }^{12}$ Essas considerações podem ser úteis para o estudo do aparecimento das lideranças carismáticas.

${ }^{13}$ Nesse ponto, é muito semelhante à teoria de Olson sobre a lógica da ação coletiva.
} 
Da mesma maneira que fez com as relações de autoridade, Coleman apresenta os sistemas de trocas sociais. As trocas muitas vezes não ocorrem entre dois atores apenas, mas em contextos complexos nos quais existe competição por recursos escassos e a necessidade de se estabelecer padrões de troca e valor ${ }^{14}$.

As trocas são sempre uma dupla coincidência de vontades. O interesse do indivíduo A em controlar o recurso que o indivíduo B controla, por um lado, e o interesse do indivíduo $\mathrm{B}$ em controlar algum recurso que está sob controle do indivíduo A. Como ambos acreditam que estarão mais satisfeitos controlando o recurso que o outro controla antes da troca, o esperado é que a troca ocorra e que ambos os indivíduos sintam-se plenamente realizados com tal transação.

As trocas, contudo, não ocorrem no vácuo. Elas ocorrem em cenários nos quais existe um competição pelo controle dos recursos entre os atores. O que define um sistema são os atores, os recursos envolvidos e a constituição, que é a distribuição inicial de controle sobre recursos dos atores. Neste sistema haverá competição por recursos escassos, existirão trocas entre os atores e um valor de troca e uma forma de moeda serão definidos. Passam a ser importantes o poder e o valor. O valor é definido como uma propriedade dos recursos e depende do interesse que os atores que detém poder têm sobre os mesmos. Já o poder é definido como uma propriedade dos atores, e corresponde ao valor total dos recursos com os quais cada ator começa a operar dentro do sistema.

A distribuição de poder dos atores e de valor dos recursos depende da distribuição de interesse e controle. A sequiência lógica de determinação dos

\footnotetext{
14 Daí a importância de se entender o papel da moeda nos mercados econômicos. Como o mercado pode ser considerado um sistema de trocas, entendendo o papel que a moeda desempenha é possível entender, apesar das diferenças, as demais trocas sociais que ocorrem.
} 
resultados é: a) dados o interesse e a distribuição inicial dos recursos (constituição), determinam-se os valores, dados pelas relações de troca, e o poder dos atores; b) com isso determina-se o equilíbrio da distribuição de controle; c) deste equilíbrio determinam-se os eventos resultantes. Para a análise de sistemas sociais reais tomase o caminho inverso, partindo dos eventos até chegar aos valores, distribuição de poder e, finalmente, aos interesses dos atores.

Outro caso importante é o das ações onde existem externalidades. Segundo Coleman, a existência de externalidades é um dos requisitos para o surgimento das normas. Dois tipos de externalidades podem ser identificados: positiva e negativa. Uma externalidade é positiva quando determinada ação beneficia outros atores. No caso de jogo tipo dilema dos prisioneiros, se ambos os jogadores colaboram, ambos ganham, do que decorreria um incentivo para ambos continuarem a colaborar ${ }^{15}$. Uma externalidade é negativa quando a ação é prejudicial a outros atores, como no caso da poluição ambiental provocada por uma empresa. A norma surge como uma forma de minimizar tal externalidade negativa. Vale lembrar, contudo, que nem todas as normas surgem da existência de externalidades.

As normas, então, podem ser entendidas como o direito socialmente adquirido de controle da ação de um indivíduo por outro, e podem também podem ser classificadas em disjuntas e conjuntas. Normas disjuntas são aquelas em que os beneficiários e os atores alvo das normas são pessoas distintas. As normas conjuntas são aquelas em que, ao contrário, beneficiários e atores alvo são os mesmos. Entre esses dois extremos, porém, são encontradas gradações significativas.

\footnotetext{
${ }^{15}$ Este tipo de análise aproxima-se da que é feita por Bicchieri(1997) quando estuda o processo pelo qual as normas são difundidas e aceitas como tal em determinados grupos.
} 
Quando as normas são conjuntas, a eficiência social tende ao ótimo, ou seja, todos ganham. Quando se trata de normas disjuntas, essa análise fica um pouco mais complicada, uma vez que sempre há ganhadores e perdedores. Passa a ser importante, então, como se dá a distribuição de recursos entre os atores. Se a distribuição é desigual, os interesses de uns contam mais do que os interesses de outros, o que pode acarretar em distorções da eficiência social da norma.

Para que a norma se efetive, é necessário ou a intervenção de uma terceira parte, que vai impor sanções aos atores caso eles não cumpram as normas, ou algum tipo de organização entre os atores envolvidos. As sanções não são entendidas apenas como negativas, mas também podem ser positivas, quando agem como incentivos aos atores $^{16}$.

Essas sanções positivas são fundamentais para compreender o conceito de zelo. Para Coleman, da mesma forma que pode existir o comportamento do tipo "carona", onde o incentivo à participação é inferior ao custo, em aguns casos pode ocorrer o inverso, ou seja, o incentivo, dadas as sanções positivas, à participação é maior que os custos. Nos dois casos, porém, a racionalidade é a mesma, uma vez que a avaliação custo-benefício feita pelo ator é considerada como favorável.

Essa análise é muito coerente com a análise proposta por Olson sobre a lógica da ação coletiva. Para ele, nos grupos grandes, existiria a necessidade de uma terceira parte que fizesse cumprir determinadas normas, uma vez que a tendência dos atores individuais, racionais e auto-interessados, é assumir comportamentos oportunistas. Já nos grupos pequenos, a possibilidade de controle mútuo das ações tenderia a

\footnotetext{
16 A influência do pensamento de Olson parece clara neste ponto do trabalho de Coleman, e será aprofundada mais adiante.
} 
minimizar tal problema, o que tornaria esses grupos mais eficientes. De qualquer forma, a idéia de que normas são necessárias parece ser recorrentes em tais trabalhos, bem como a existência de sanções para que elas sejam efetivas ${ }^{17}$.

As normas são entendidas também como regras $($ Ostrom,1986) ou ainda como instituições. Para North (1990), instituições são as regras do jogo em uma determinada sociedade. São o conjunto de limitações que os homens criam para limitar e definir as formas de interação humana. São regras que podem ser formais, como por exemplo a Constituição de um país, ou informais, como os códigos de conduta e as convenções sociais. Para ele, as instituições são criadas ou podem evoluir espontaneamente, e sua principal função é reduzir as incertezas e fornecer uma estrutura estável para a vida cotidiana, ainda que isso não garanta que as instituições sejam eficientes ou que durem indefinidamente ${ }^{18}$.

As instituições diferem das organizações em muitos aspectos, apesar de serem comumente tomadas como sinônimos. Enquanto as instituições definem o arcabouço de uma sociedade, com regras de comportamento e oportunidades relacionadas, as organizações, que são grupos de indivíduos com objetivos comuns, são criadas para tirar vantagem dessas oportunidades; a interação entre as instituições e as organizações é que vai configurar o processo de mudança institucional. Pode-se afirmar, desta maneira, que as organizações são agentes dos processos de mudança institucional, sendo, por outro lado, influenciadas pelas próprias mudanças, num dinâmico processo de transformação.

\footnotetext{
17 A análise de Olson sobre a ação coletiva será novamente abordada por Elinor Ostrom, quando esta critica a sua aplicação na formulação de políticas para bens comuns.

18 Aliás, aos processos de mudança institucional deve ser dada ênfase especial, uma vez que são essas mudanças que modelam a forma como as sociedades evoluem ao longo do tempo, sendo de vital importância para o entendimento das mudanças históricas.
} 
Um exemplo de instituição informal, muito encontrada no meio rural, é a troca de serviços, ou então os mutirões em períodos de concentração de tarefas, como a colheita. No caso do assentamento Gleba Ribeirão Bonito, essa prática é muito comum, o que foi utilizado pelas organizações ambientalistas para organizar os grupos de trabalho que iriam se dedicar às atividades de conservação ambiental. Por outro lado, o exercício do trabalho coletivo nas atividades de conservação ambiental reforça a instituição que indica que o trabalho coletivo, em algumas situações, é muito mais desejável do que o trabalho individual.

O conjunto de regras que vão determinar um comportamento contrário ao habitual, que consistia em ver na floresta um espaço de utilização individual livre (para a caça ou extração de madeira, por exemplo), supõe um certo ambiente institucional, um conjunto de normas e valores que norteiam as ações dos indivíduos e suas relações uns com os outros

A questão, porém, passa a ser a seguinte: como surgem e se mantém as instituições ou as normas?

Bicchieri (1997), que entende que as normas são um meio de se atingir um determinado fim social que é aceito em uma determinada época e contexto social, busca respostas para essa questão. Para ela, a manutenção de uma norma é um problema de ação coletiva: ninguém quer ser o primeiro a violar a norma, pois estaria sujeito a sanções. O comportamento racional, portanto, é o cumprimento da norma. Porém, em alguns casos, não existe sanção para o cumprimento da norma e, mesmo assim, ela é aceita por todos os indivíduos de uma sociedade. Existiria, segundo ela, uma internalização da norma. As pessoas desenvolvem sanções internas e sentem-se culpadas quando não cumprem a norma. Isso pode ser ocasionado por um processo 
cognitivo que merece destaque na abordagem de Bicchieri: as normas emergem pelo aprendizadoOs indivíduos aprendem a se comportar de determinada maneira e internalizam tal comportamento, que pode se transformar em uma norma, mas a base tanto do comportamento como da mudança é uma determinada estrutura de incentivos, muito mais do que uma "tomada de consciência". Portanto, normas são fruto de um processo de escolhas, em um contexto de interação estratégica entre os indivíduos. O conceito de dependência de caminho ajuda a compreender melhor a formulação anterior: "a cada passo ao longo do caminho houve escolhas - políticas e econômicas - que ofereceram alternativas reais. Dependência de caminho (path dependence) é uma via para estreitar conceitualmente o conjunto de escolhas e ligar a tomada de decisão através do tempo. Não é uma história da inevitabilidade na qual o passado quase prediz o futuro." Contudo, “...uma vez disposto um certo caminho de desenvolvimento, a rede de externalidades, o processo de aprendizagem das organizações e a modelagem subjetiva das questões, historicamente derivada reforça o curso" (North, 1990, apud Abramovay 2001).

Para Bicchieri (1997), as normas estão relacionadas ao conceito de equilíbrio, e os indivíduos tendem a repetir padrões de comportamento que aprenderam e que já utilizaram com sucesso em outras situações e ambientes.

Para Witt (1989), as normas se propagariam através de um processo de difusão simples, e a frequiência de ocorrência da norma na população é que influenciaria no processo de tomada de decisão dos atores em adotar ou não a norma. Para ele, quanto mais atores adotam a norma, maior é a probabilidade de outros atores adotarem, esperando com essa atitude auferir maiores ganhos individuais. Existiria, portanto, 
um número mínimo de adotantes para que a norma se efetive. Quando esse número é atingido, mais indivíduos irão adotar a norma.

Para Bicchieri (1997), porém, existem dois mecanismos de propagação das normas. Um válido para os grupos pequenos, onde os indivíduos, através da interação, sinalização e experimentação, "aprenderiam" a adotar determinadas normas. Nos grupos grandes, os atores tenderiam a reproduzir o aprendizado adquirido nos grupos pequenos, seguindo então a lógica da propagação simples. Porém, para a autora existe, nos grupos grandes, a influência de mecanismos evolutivos, que influenciariam a manutenção ou não da norma ${ }^{19}$.

Como para Olson, o tamanho do grupo também é uma questão relevante. Nos grupos pequenos, existe a possibilidade de interação estratégica entre os atores, fazendo com que a sinalização exista e possibilite o aprendizado. Nos grupos grandes, a ação ocorre entre anônimos, o que impede a ocorrência do aprendizado. A diferença, portanto, reside na possibilidade de perceber o retorno da ação individual através da ação dos demais atores.

Ainda discutindo a importância das instituições para a coordenação de ações coletivas, encontramos no trabalho de Ostrom (1990) uma interessante análise sobre as alternativas institucionais para a administração de bens comuns, com destaque para a auto-gestão dos grupos.

A autora inicia seu trabalho com uma crítica às construções teóricas que dão suporte para a formulação de políticas para o manejo de bens comuns, em especial os recursos naturais. Essas teorias, quando aplicadas à realidade, podem levar a equívocos que influenciam de forma desastrosa o manejo dos recursos.

${ }^{19}$ Porém, é no grupo pequeno que a norma é gerada. 
A primeira delas é aquela que ficou conhecida como "tragédia dos comuns", citado no início deste texto. Segundo esta teoria, proposta por Hardin (1968), os recursos naturais estariam fadados ao esgotamento, dado o comportamento racional e auto-interessado (egoísta) dos indivíduos. Como cada indivíduo pretende maximizar o lucro individual, há a tendência de ocorrer uma super exploração do recurso, com prejuízos no longo prazo. A racionalidade dos indivíduos levaria, portanto, a uma utilização coletiva desastrosa e com prejuízo no futuro, uma vez que os recursos se esgotariam.

A segunda crítica é direcionada ao dilema dos prisioneiros. Segundo tal teoria, não existe a possibilidade de cooperação entre os dois jogadores, mesmo sendo esse o comportamento que mais beneficiaria a ambos. Como os indivíduos são racionais, a escolha, baseada nessa racionalidade, recai em estratégias inferiores, o que leva a resultados sub-ótimos do ponto de vista coletivo ${ }^{20}$.

Outra teoria que influencia a formulação de políticas para a administração dos recursos naturais é desenvolvida por Olson, já exposta neste texto. Segundo o autor, haveria uma séria limitação para que os indivíduos assumissem comportamentos coletivos de cooperação que resultassem em melhor uso dos recursos naturais. A possibilidade de comportamento oportunista (tipo carona) seria um sério entrave e levaria também à super exploração do bem comum.

Essa três formulações teóricas (a lógica da ação coletiva, o dilema dos prisioneiros e a tragédia dos comuns) têm em comum o fato de que partem do indivíduo e apresentam um elevado grau de ceticismo quanto à possibilidade de a

\footnotetext{
20 Contudo, um dos esforços mais interessantes nas ciências sociais desde meados dos anos 1980 é mostrar que o ceticismo envolvido no dilema dos prisioneiros atenua-se fortemente a partir do momento em que o jogo se torna repetitivo e que os atores têm a possibilidade de aprender com a experiência (Axelrod,1997).
} 
ação coletiva, deliberada e voluntária, acontecer. Assumindo que a racionalidade individual não se traduz em racionalidade coletiva, acabam levando a uma visão extremamente pessimista a respeito da utilização dos recursos naturais, que estariam condenados ao esgotamento devido à exploração em quantidade acima do ótimo.

Porém, esses modelos, quando aplicados à formulação de políticas para os bens comuns, podem provocar sérias distorções, pois são estáticos e não levam em conta que as regras podem ser alteradas ao longo do tempo. Ao considerar apenas tais formulações teóricas, as políticas propostas vão em direção a dois extremos: a regulação por uma agência central (solução "hobbesiana") ou a privatização e controle dos recursos pelo mercado.

Essas duas propostas de política têm se mostrado insuficientes (ou mesmo desastrosas), o que implica na necessidade de encontrar um novo instrumental teórico que dê conta de casos empíricos onde outras formas de exploração dos recursos são utilizadas ${ }^{21}$.

O principal problema da regulação centralizada é o alto custo de informação, uma vez que a agência não tem condições de conseguir informação completa e, consequentemente, não tem condições de monitorar e fazer cumprir de maneira eficiente as normas que impõe para a utilização dos recursos ${ }^{22}$.

Por outro lado, a privatização dos recursos esbarra na necessidade de definição entre bens excludentes e não excludentes, no fato de não se poder privatizar bens comuns (apenas regular sua utilização), e em questões relacionadas à definição de direitos e deveres. Em resumo, esses detalhes institucionais são de fundamental importância.

${ }^{21}$ Justamente como faz Elinor Ostrom ao buscar um caminho que evite essa polaridade e que envolve as instituições que permitem a acumulação de capital social. 
Em contraposição a esses dois extremos, a realidade mostra que grupos de indivíduos se apoiam em instituições alternativas para manejar recursos, obtendo sucesso em boa parte dos casos. Nessas instituições, as regras podem ser alteradas de acordo com a vontade dos indivíduos, podendo levar a resultados que não sejam trágicos como pressupõem as teorias convencionais.

Porém, faltam ainda instrumentos teóricos de análise de tais experiências, além de não existir uma solução única para tais problemas, mas várias soluções para diferentes situações. Uma das soluções alternativas é dada pelos próprios atores quando esses negociam (ex-ante) um contrato de ação cooperativa. Em grupos pequenos, os próprios atores podem monitorar e "fazer cumprir" as decisões acordadas. Todos os membros precisam internalizar o acordo, sem o que a ação coletiva não ocorre. Os aspectos positivos desta forma de ação é que o grupo (e os indivíduos) ganha autonomia, o saber local é valorizado e a auto-estima aumenta ${ }^{23}$.

A pergunta central, a ser respondida por meio de um esforço teórico, é por que em alguns lugares os indivíduos têm sucesso e em outros lugares não? Quais as variáveis internas e externas que limitam ou estimulam a capacidade dos indivíduos em resolver seus problemas? Ou ainda, como sair de uma situação onde predominam as ações independentes para a adoção de estratégias coordenadas que melhorem o suprimento de benefícios coletivos?

Quando se recorre à teoria do Estado ou à teoria da Firma, essas condições são supridas pelo agente externo, que pode: a) criar novas instituições; b) exigir o comprometimento dos indivíduos; e c) monitorar o comportamento dos atores.

\footnotetext{
${ }^{22}$ Parques e Reservas Florestais que existem apenas no papel são um bom exemplo disto.

${ }^{23}$ A autora usa o exemplo de uma comunidade pesqueira na Turquia.
} 
Porém, outras soluções são encontradas, sem a necessidade de recorrer a estas teorias.

A noção de capital social, exposta em trabalhos como o de Putnam (1993/1996) sobre a região norte da Itália, onde a existência de instituições cívicas milenares influenciam e estimulam a cooperação entre os atores, é útil para a compreensão dos fatores que podem levar a melhores resultados do ponto de vista coletivo, ainda que não contribua muito para explicar o surgimento de novas instituições e o comprometimento dos indivíduos com elas. Ao contrário, surgem novas dúvidas, como mostra Abramovay (2000), citando Durston (1998): como criar capital social ali onde ele não existe? Como estimular comportamentos cooperativos nos locais onde não existe tal tradição cooperativa?

No caso dos assentamentos do Pontal do Paranapanema, um dos fatores que explica o surgimento de comportamentos cooperativos relacionados à conservação da natureza é a existência de uma estrutura de incentivos dada pela ação da rede de organizações, ou seja, por um agente externo que estimula tal tipo de comportamento. Exatamente por ser um assentamento, a ação coletiva não se apoia sobre uma forte tradição anterior de confiança entre os atores acumulada ao longo de sua história. Isso significa, portanto, que é possível, através de um esforço sistemático, criar as condições apropriadas para que ações coletivas sejam articuladas e levadas a efeito pelos atores. Porém, não é possível avaliar até que ponto tal comportamento é realmente incorporado pelos atores, como será demonstrado adiante. 


\section{6- EVIDÊNCIAS EMPÍRICAS DO ESTUDO DE CASO}

Este capítulo apresenta as principais evidências empíricas levantadas durante o trabalho de campo. Tais evidências corroboram as hipóteses levantadas durante o período de elaboração do projeto. Com base na discussão teórica apresentada anteriormente, o trabalho de campo buscou respostas para as seguintes perguntas: 1) é possível afirmar que as famílias de trabalhadores rurais assentadas estão efetivamente transformando as suas práticas culturais, direcionando seus esforços para a construção de um modelo de exploração da terra que leve em conta a conservação da natureza?; 2) pode-se afirmar que essa transformação tem relação causal direta com a disponibilização de uma estrutura de incentivos dada pela ação de uma rede de organizações que atua na região? e 3) em que grau esta transformação está se incorporando na vida dessas famílias e se tornando uma nova regra de conduta ou, para usar um termo utilizado com freqüência, uma nova instituição?

Assim, este capítulo está dividido em três partes, além desta introdução. A primeira apresentará as principais evidências empíricas que respondem à primeira das questões colocadas: é possível afirmar que as famílias de trabalhadores rurais assentadas estão efetivamente transformando as suas práticas culturais, direcionando seus esforços para a construção de um modelo de exploração da terra que leve em conta a conservação da natureza?

Sendo a resposta à pergunta anterior afirmativa, é apontada, então, a relação que tais transformações têm com a estrutura de incentivos disponibilizada pela rede 
de organizações que atua na região. Espera-se demonstrar que as transformações no uso da terra (e, em última instância, na própria relação das pessoas com a natureza), que incorporam gradualmente a preocupação com a conservação ambiental, são estimuladas e levadas a efeito pela existência de tal estrutura de incentivos. Assim, esta parte do capítulo dedica-se a entender como funciona esta estrutura e qual é efetivamente a sua influência nas transformações das práticas de manejo do lote das famílias.

A seguir são apresentadas evidências de que estas transformações que vêm ocorrendo na região estão sendo incorporadas de tal forma nas práticas das famílias assentadas, no discurso de suas lideranças e na ação dos técnicos que assessoram estas famílias, que gradualmente podem adquirir o status de uma nova regra de conduta ou, para falar como Douglas North (1990), de uma nova instituição.

\section{1- As principais transformações nas práticas de manejo dos lotes pelas famílias assentadas}

Aqui são apontadas as principais transformações que estão ocorrendo nas práticas de manejo dos lotes das famílias assentadas da Gleba Ribeirão Bonito, prioritariamente aquelas localizadas na divisa do assentamento com o Parque Estadual do Morro do Diabo e aquelas que circundam um dos fragmentos florestais que, com outros, compõem a Reserva Florestal Legal do assentamento.

Uma primeira evidência das transformações pode ser verificada quanto à utilização do solo dentro do lote. Neste assentamento, como na maioria dos outros projetos de assentamento da região, os lotes familiares variam de 15 a 25 ha, nos quais as famílias têm que garantir a sua sobrevivência. $O$ que se verifica é que a 
produção para o autoconsumo é um dos principais componentes dos sistemas de produção adotados, sendo também importante fonte de renda dos assentados. Segundo dados do ITESP (1998), as atividades de autoconsumo existentes nos assentamentos do estado de São Paulo, como a criação de aves e suínos e o cultivo de frutas e hortaliças, que sempre ocorrem próximos à moradia, no entorno da casa, contribuem significativamente para garantir a segurança alimentar das famílias. Também a agricultura para o autoconsumo, como o cultivo de arroz, milho, feijão e mandioca, são um componente importante dos sistemas de produção dos assentamentos rurais $^{24}$. O quadro que se apresenta, portanto, traz como principal elemento a questão da segurança alimentar. Ora, se temos, por um lado, o tamanho relativamente reduzido do lote familiar, e de outro, a preocupação básica em garantir a segurança alimentar, era de se esperar que a última atividade a que estas famílias assentadas se dedicariam fosse a incorporação de espécies florestais nos seus lotes, uma vez que tais espécies demoram bastante para crescer (quando comparadas aos cultivos anuais) e, muitas vezes, não têm valor de mercado. O surpreendente, então, é que as famílias que estão sendo assistidas pela rede de organizações têm utilizado áreas consideráveis do seu lote para as atividades agroflorestais ${ }^{25}$.

Nas entrevistas com as 27 famílias, todas implantaram pelo menos 01 ha de sistemas agroflorestais, como maior ou menor diversidade de espécies florestais, segundo a preferência individual. Destas, 11 famílias estão destinando entre 01 e 02 ha para as atividades agroflorestais. Numa aproximação grosseira, pode-se afirmar,

\footnotetext{
${ }^{24}$ Para maior aprofundamento e acesso aos dados utilizados, ver Retrato da Terra 97/98, ITESP (1998).

${ }^{25}$ Contrariando o que defende Hardin (1968) em seu artigo sobre a Tragédia dos Comuns.
} 
portanto, que utilizam de 5 a $10 \%$ da sua área para estas atividades ${ }^{26}$. A área utilizada para a implantação dos sistemas agroflorestais integra o sistema de produção, fazendo com que este se torne mais diverso e mais equilibrado ecologicamente. Além disso, introduzem uma grande variedade de espécies florestais que são extremamente importantes do ponto de vista da manutenção da biodiversidade regional, conforme demonstrado anteriormente.

Uma outra evidência que demonstra a transformação no relacionamento entre as famílias e a natureza é com relação à caça. Entrevistas com os guardas florestais do Parque Estadual do Morro do Diabo deixaram claro que após a implantação definitiva dos lotes do assentamento, a incidência de caça nesta área diminuiu significativamente. Os guardas atribuem tal diminuição ao maior cuidado que as famílias assentadas têm em controlar o acesso ao seu lote e, consequentemente, à área do Parque. Assim, na visão dos guardas do Parque, o assentamento das famílias no entorno da Unidade de Conservação está contribuindo de forma significativa para o manejo da mesma. Além disso, segundo estes mesmos entrevistados, os assentados são muito mais cuidadosos no manejo do fogo. Antes do assentamento, como a área estava desocupada, eram constantes as ameaças de incêndio. Como os assentados agora estão manejando as áreas adjacentes ao Parque e identificam nos guardas e nos técnicos do IPÊ aliados importantes para as suas estratégias de reprodução, invariavelmente pedem auxílio e orientação para estes quando necessitam colocar fogo em alguma área de seus lotes ( o uso do fogo ainda é uma das práticas muito

\footnotetext{
${ }^{26}$ Como nestes lotes os sistemas agroflorestais são implantados em faixas que acompanham a divisa do lote, o cálculo desta área foi estimado através da quantidade de mudas utilizadas nos plantios, da largura da faixa de implantação do sistema e da distância da divisa de cada lote. Considerou-se desnecessária a medição precisa das áreas para efeito deste estudo, uma vez que para o que se pretende demonstrar uma simples estimativa é o suficiente. Isso não exclui, porém, a importância de se obter esses dados. Neste sentido, o IPÊ vem utilizando, com sucesso, fotografias aéreas para o monitoramento da taxa de cobertura vegetal nes tas áreas.
} 
utilizadas para o manejo de pastagens na região), o que faz com que se possa exercer um controle muito maior sobre esta prática que pode, se for feita sem cuidado, causar danos significativos à integridade da Unidade de Conservação. Assim, além do efeito direto de proteção florestal que estas faixas de áreas vegetadas desempenham, elas acabam por induzir uma proteção adicional e indireta, na medida em que as famílias passam a utilizar o fogo de forma mais controlada e de acordo com as recomendações técnicas dos funcionários do Parque.

Outro aspecto interessante que apareceu nas entrevistas com as famílias assentadas é o destaque para a capacitação em manejo agroflorestal. As famílias, ao integrarem as atividades promovidas pela rede de organizações, recebem, através de cursos rápidos realizados na sede do Parque Estadual do Morro do Diabo, as informações necessárias para que comecem a manejar os sistemas agroflorestais nos seus lotes. Nos cursos são passados conhecimentos a respeito das principais espécies arbóreas adaptadas às condições edafoclimáticas regionais, os principais consórcios entre espécies arbóreas e não arbóreas, produção de mudas, tratos culturais e a importância ecológica das atividades agroflorestais na região do Pontal do Paranapanema. Segundo as famílias, foi através destes cursos que tomaram contato pela primeira vez com a possibilidade de manejar a terra de formas alternativas. O mito de que só é possível fazer agricultura na forma de monocultivos parece ter sido quebrado, e os assentados já conseguem elaborar os seus próprios consórcios, segundo os seus interesses individuais. Se atentarmos para a proposição de Sen (2000), para quem "desenvolvimento deve ser entendido como o aumento da capacidade dos indivíduos fazerem escolhas", podemos afirmar que o processo de capacitação que estas pessoas estão vivendo tem feito com que a sua capacidade de 
decidir sobre as formas como desejam manejar os seus lotes aumente significativamente.

Nas palavras do Miro, um dos assentados da Gleba Ribeirão Bonito, “agora a gente sabe que é possível misturar um monte de espécies, usar mais a terra...onde antes a gente plantava só feijão, agora tem um monte de árvore no meio...daqui um tempo, a gente colhe o feijão e as árvores tão lá, crescendo e deixando o lote mais bonito”.

Nesta declaração, escolhida por representar uma visão recorrente nas entrevistas com os assentados, dois aspectos aparecem de forma contundente. O primeiro deles é quanto à possibilidade de utilizar de forma mais intensiva o solo, ou seja, os assentados perceberam que, através dos consórcios de espécies, podem utilizar de forma mais eficiente um dos recursos mais escassos que detêm, que é o solo. Após colher o feijão, as árvores continuam crescendo, e poderão no futuro ser utilizadas no próprio lote ou comercializadas. Com a disponibilização destes conhecimentos, a decisão de utilizar estes sistemas no seu lote passa a ser do assentado. As organizações e os assentados, como demonstrado anteriormente, passam a interagir num verdadeiro jogo onde ambas as partes podem ganhar. Por um lado, os assentados adquirem novos conhecimentos e podem tomar decisões a respeito do futuro do seu lote com maior autonomia. Por outro lado, as organizações, ao disponibilizarem tais conhecimentos, acabam por induzir os assentados a experimentarem, em uma pequena área do seu lote, a implantação dos sistemas agroflorestais, o que é, para estas organizações, o principal objetivo. Assim, através da transação entre as partes, vai sendo construída uma nova forma de conduzir as 
atividades nos lotes do assentamento que incorpora gradualmente a preocupação com a conservação da natureza.

$\mathrm{O}$ outro aspecto que aparece no depoimento do Miro é aquele relacionado à estética do lote. Como são assentadas em locais que anteriormente eram destinados à exploração de pecuária extensiva, as famílias, ao se instalarem nos lotes definitivos, encontram uma paisagem verdadeiramente desoladora. As casa são construídas no meio de pastagens degradadas. Isso faz com que a implantação dos sistemas agroflorestais tenha também o componente de embelezamento do lote, uma vez que o que as famílias assentadas estão procurando ao se engajar no processo de reforma agrária não é apenas conseguir um local para produzir alimentos e fibras, mas um local para viver com dignidade. Nas palavras do Bil (Valmir Rodrigues Chaves, na época presidente da Cocamp e assentado na Gleva XV de Novembro), quando da abertura do seminário sobre Reforma Agrária e Agroecologia, realizado em 2000 na sede do Parque Estadual do Morro do Diabo, este aspecto de embelezamento dos lotes fica claro: "o que a gente precisa é fazer esses assentamentos ficarem mais bonitos, encher eles de árvores...aí vai ter os passarinhos e os bichos de volta, que agora não tem mais nada, é só capim pisado...”.

Se lembrarmos as proposições de Coleman (1990), podemos evidenciar empiricamente que está ocorrendo uma transação entre as famílias assentadas e as organizações ambientalistas, ou seja, parte do controle do recurso (solo) que as famílias detém está sendo dividido com as organizações, que por sua vez disponibilizam para as famílias assentadas um recurso (conhecimento agroflorestal e incentivos financeiros, como mudas de espécies florestais, combustível para o preparo do solo, entre outros que serão apresentados no item 7.2) que cada vez mais 
as interessa. O resultado concreto dessa transação é a implantação dos sistemas agroflorestais, tanto no entorno do Parque Estadual do Morro do Diabo quanto para a composição de um corredor ecológico dentro da área do assentamento. O controle sobre parte do lote é compartilhado, então, entre assentados e os técnicos das organizações que compõem a rede, conforme pôde ser verificado nas nossas atividades de pesquisa.

Por um lado, os técnicos pretendem que os assentados implantem determinados modelos de sistemas agroflorestais, priorizando a diversidade e a raridade das espécies florestais. Por outro lado, os assentados tendem a priorizar a utilização de espécies que cresçam rápido e tenham utilidade prática dentro do lote ou então tenham valor comercial, com destaque para as diferentes variedades de eucalipto. Este conflito de interesses é o pano de fundo para o processo de tomada de decisão sobre o sistema que vai ser implantado. Decisões como espaçamento, disposição das espécies, quantidades e diversidade, devem ser negociadas, num constante aprendizado de relacionamento entre as partes. $\mathrm{O}$ relato a seguir evidencia as colocações acima: os técnicos do IPÊ e do Parque haviam levado caixas de isopor com as mudas de espécies florestais para o assentamento. Como havia sido combinado com antecedência, várias famílias esperavam a chegada do caminhão com as mudas. Durante a distribuição, ficou evidente o interesse das partes. Os assentados queriam mudas de eucalipto, justificando a preferência pela espécie com argumentos prioritariamente financeiros. Os cálculos de quanto se pode economizar com o plantio de um bosque de eucalipto dominou rapidamente a discussão. Por outro lado, os técnicos que haviam levado as mudas pretendiam que as famílias plantassem também espécies como o cedro ( Cedrella fissilis), o jaracatiá (Jaracatia 
spinosa), o mulungu (Erythrina mulungu) e o ipê (Tabebuia ocharacea). Após intensa negociação, ficou definido que as famílias receberiam as mudas de eucalipto com a contrapartida de plantarem também as outras espécies, numa proporção de pelo menos $20 \%$ de espécies nativas. Esta negociação mostra também um aspecto delicado do trabalho de extensão rural realizado pelas organizações, pois ao mesmo tempo em que elas entendem como importante a participação e a autonomia das famílias em escolher os sistemas que vão implantar, por outro lado não podem abrir mão de determinados critérios técnicos que dão o embasamento científico ao projeto. Assim, a linha que separa a imposição da sugestão é bastante tênue, o que implica em uma necessidade adicional de negociar com as famílias os modelos que serão implantados nos lotes que, afinal de contas, estão sob o seu controle direto, principalmente por não se tratar de áreas de preservação permanente ou de reserva florestal legal.

Aliás, é este aspecto que torna ainda mais instigante a investigação. Se a implantação dos sistemas agroflorestais se desse em áreas deste tipo, poderíamos inferir que os assentados estariam simplesmente tendo um comportamento racional, uma vez que as mudas de espécies florestais estariam sendo disponibilizadas de forma gratuita e, como eles teriam necessariamente que recompor tais áreas, evitariam os gastos com a aquisição ou produção das mudas. Porém, a implantação dos sistemas ocorre nas áreas destinadas à exploração agropecuária dos lotes. A primeira pergunta que faria alguém que acaba de chegar à região é porque esses assentados estariam adotando esta estratégia? Esse pessoal do MST é tão maluco assim que deixa de produzir para plantar árvores? Afinal, eles não queriam terra para produzir alimentos? 
Para responder as perguntas do nosso ilustre visitante precisamos entender melhor a lógica das famílias assentadas e de suas lideranças. Em primeiro lugar, estas famílias estão se envolvendo nestes projetos porque vislumbram, no futuro, retornos econômicos do investimento que estão fazendo no presente, ou seja, não existe qualquer evidência de que as ações são movidas puramente por comportamentos do tipo altruísta (ainda que este tipo de comportamento possa estar presente em várias das pessoas que estão implantando os sistemas). Ao contrário, podemos afirmar que existe um cálculo racional feito pelos assentados dos retornos que tal atividade irá proporcionar. Nas conversas com os assentados os cálculos eram feitos com muita clareza. Em uma das conversas, o entrevistado sabia dizer exatamente o quanto poderia economizar com a compra de palanques de eucalipto dali a sete anos. Como ele implantou uma área de 0,5 ha de eucalipto com espaçamento de $3 \mathrm{~m} \times 3 \mathrm{~m}$, num total de 555 mudas, ele espera obter um retorno econômico de $\mathrm{R} \$ 2.800,00$, vendendo a dúzia de palanques a $\mathrm{R} \$ 60,00$ ( ou ainda deixando de comprar no mercado para suprir as próprias necessidades). Isso significa uma renda bruta por hectare de $\mathrm{R} \$ 5.600,00$ em sete anos, que é o tempo entre o plantio e a colheita do eucalipto, ou seja, uma renda bruta de $\mathrm{R} \$ 800,00$ por ha/ano. No caso em questão, como os custos de implantação ficaram bastante reduzidos devido à estrutura de incentivos (preparo do solo e mudas) disponibilizada pelas organizações (que será detalhada no item 7.2) , a perspectiva de geração de renda é bastante interessante. Para simples efeito de comparação, utilizamos uma das atividades que têm maior importância econômica nos sistemas de produção característicos do assentamento e da região. A produção de leite é realizada, apesar de todos os esforços dos técnicos do ITESP no sentido de tornar mais eficientes os sistemas de produção, de forma 
ainda bastante extensiva. Para efeito de cálculo, utilizamos a lotação animal de 1 unidade animal por hectare. Se uma vaca leiteira produzir $1.500 \mathrm{~kg}$ de leite durante uma lactação, e o leite for vendido a um preço médio de $\mathrm{R} \$ 0,30 / \mathrm{kg}$ de leite, tem-se uma receita bruta anual aproximada de $\mathrm{R} \$ 450,00 / \mathrm{ha} / \mathrm{ano}$, ou seja, uma diferença significativa quanto à geração de renda bruta.

É este tipo de estimativa que passou a ser levado em conta pelas famílias ao decidirem se devem ou não se incorporar ao esforço coletivo de implantação dos sistemas agroflorestais. Assim, pode-se afirmar que a dimensão econômica do processo de troca social que está em curso é de extrema importância, não devendo ser negligenciada nos projetos que visam a conservação ambiental e ao desenvolvimento sustentável. Não se pretendeu, como pode ser observado, fazer um levantamento criterioso do potencial de geração de renda que têm as atividades agroflorestais, mas identificar como se dá a percepção dos assentados em relação ao potencial de geração de renda de tais sistemas.

Com a apresentação destas evidências espera-se ter demonstrado que transformações efetivas estão ocorrendo nas práticas culturais das famílias assentadas, em especial no que se refere ao trato do solo, contribuindo para a conservação da natureza em uma região que apresenta um dos maiores índices de degradação ambiental do estado de São Paulo. 


\section{2 - A estrutura de incentivos para as transformações nas relações entre sociedade e natureza.}

Após ter demonstrado que as transformações das práticas das famílias assentadas estão efetivamente ocorrendo, cabe relacionar estas transformações aos fatores que as estão condicionando. Afirmamos desde o início do projeto de pesquisa que era a existência de uma estrutura de incentivos oferecida por uma rede de organizações o principal fator que impulsiona as transformações nas práticas das famílias, que gradualmente incorporam a conservação ambiental nas suas atividades.

Para tanto, é necessário que seja apresentada com maior profundidade como funciona esta estrutura de incentivos e qual é a dinâmica desta rede de organizações.

Por estrutura de incentivos entende-se todo o aparato técnico, financeiro e científico tornado disponível às famílias que se inserem nas atividades agroflorestais. No caso deste projeto, as atividades sistemáticas de pesquisa ficaram circunscritas ao assentamento Gleba Ribeirão Bonito, devido à sua proximidade com o Parque Estadual do Morro do Diabo e por ter sido o primeiro assentamento trabalhado de forma sistemática pelas organizações. Isso não significa, contudo, que este assentamento seja o único que se integra nas atividades de conservação ambiental. Ao contrário, ele tem papel fundamental na disseminação da idéia de se implantar sistemas de produção que possam ao mesmo tempo gerar renda para as famílias assentadas e contribuir para a conservação da natureza. Atualmente, existem famílias de 9 assentamentos desenvolvendo algum tipo de atividade relacionada a sistemas agroflorestais, quer seja através da implantação de viveiros comunitários ou, mais recentemente, na experimentação de consórcios de espécies florestais com café. 
Para que estes projetos possam acontecer, a rede de organizações precisa constantemente conseguir apoio para as suas iniciativas. Essa necessidade de apoio, aliás, pode ser considerada um dos principais motivos da articulação das organizações. Isso porque, dado o histórico de cada uma delas, se tornou cada vez mais imperativo que elas se congregassem através de projetos cooperativos, sem o que a própria sobrevivência das mesmas ficaria comprometida. Para entender como isso ocorre, é necessário entender cada uma das organizações, sua trajetória e objetivos, bem como as transformações que estão vivendo.

A primeira delas, o Instituto de Pesquisas Ecológicas (IPÊ), surge através da articulação de um grupo de cientistas ligados à conservação da natureza. Conforme foi mostrado anteriormente, suas atividades, no início da sua constituição formal, estavam ligadas prioritariamente à conservação de espécies ameaçadas de extinção, sendo a principal delas o micoleão-preto. $\mathrm{O}$ financiamento para este trabalho vinha de organizações ambientalistas internacionais e nacionais, numa dinâmica que funciona até hoje e que garantiu (e ainda garante) a continuidade das ações de conservação. Porém, este tipo de financiamento, na forma de pequenas doações a fundo perdido para pequenos projetos de pesquisa em vida silvestre, não permitia saltos maiores como os que passaram a ser dados após a consolidação das parcerias e alianças estratégicas.

Efetivamente, os principais projetos em andamento do IPE ( e que são os que têm maiores orçamentos) são aqueles em que as parcerias com os movimentos sociais, com universidades e com o Estado foram fundamentais. Os projetos que impulsionaram os trabalhos com sistemas agroflorestais foram o "Abraço Verde" (realizado atualmente no assentamento Tucano, é financiado pelo PPG7 através do 
Programa PD/A - Projetos Demonstrativos Tipo A) e o "Ilhas de Biodiversidade como corredores na restauração da paisagem fragmentada do Pontal do Paranapanema” (financiado pelo PRONABIO - Programa Nacional de Diversidade Biológica, do Ministério do Meio Ambiente, em que o IPÊ é a organização responsável e a ESALQ, a COCAMP, o IF e o MST são parceiros) e têm em comum o fato de serem projetos coletivos. Esses projetos, portanto, só puderam ser colocados em andamento a partir da formação de uma aliança entre as diferentes organizações. Assim, para que o IPÊ pudesse ampliar o escopo da sua atuação, foi preciso estabelecer diversas parcerias com outras organizações, que ao mesmo tempo em que auxiliam o trabalho do IPÊ passam a também se beneficiar da parceria.

A ESALQ, por exemplo, após o início dos trabalhos no Pontal, atualmente desenvolve projetos com outros financiamentos, em que o IPÊ é uma das organizações parceiras, junto com a COCAMP e o MST, sendo a Universidade a organização coordenadora.

Enfim, o que se pretendeu demonstrar é que a partir da construção desta rede de organizações, todas se fortalecem, o que é evidenciado pelo aumento da quantidade de recursos disponíveis para os projetos. Conforme mostra Latour (2000), cada uma destas organizações mobiliza a inteligência estratégica para continuar realizando o trabalho que dá sentido à sua existência. A Universidade consegue recursos para realizar pesquisas, o IPE consegue recursos para também realizar pesquisas e implementar projetos que vão contribuir para a conservação da natureza, a COCAMP consegue maior credibilidade junto aos seus associados ao possibilitar a realização dos projetos, o MST acaba por associar a idéia de responsabilidade ambiental à sua luta por reforma agrária, o IF passa a ter menos problemas com a manutenção da 
integridade da Unidade de Conservação sob a sua responsabilidade, o ITESP ganha importantes aliados para o seu trabalho de promover melhores condições de vida para as famílias assentadas, enfim, a construção destas alianças permite que sejam mobilizados recursos que passam a ficar disponíveis para algumas famílias assentadas na região do Pontal do Paranapanema. Essa característica, a formação de pactos territoriais voltados ao desenvolvimento regional sustentável, pode levar as populações locais a novos patamares de qualidade de vida (Ehlers,1998/1999; Veiga,1999; Abramovay, 2001; Abramovay 2002). Os documentos de discussão da Agenda 21 Brasileira, ao tratarem o tema da agricultura sustentável, apontam claramente para a importância crucial da formação de pactos territoriais voltados à criação de condições propícias ao desenvolvimento rural sustentável.

Porém, as relações entre as organizações que compõem tal rede não são, na maioria das vezes, simétricas. $\mathrm{O}$ que se percebe é que as organizações dos assentados, tanto a COCAMP quanto o MST, têm maiores dificuldades em conseguir recursos para os projetos. Em nenhum dos projetos desta aliança o MST ou a COCAMP é a organização responsável junto à entidade financiadora, mesmo com toda a inserção do MST nos organismos internacionais de financiamento de projetos sociais, em especial aqueles ligados às Igrejas. A situação é quase um paradoxo, pois é a imagem do Movimento Sem Terra que contribui para o levantamento dos recursos para os projetos, mas é também essa imagem que faz com que os financiadores repassem os recursos para outras organizações, que passam a ser as responsáveis diretas pelos resultados dos projetos.

Esse fato faz com que alguns conflitos apareçam com freqüência entre as diferentes organizações. Em entrevista com os técnicos da COCAMP, um deles, 
falando sobre como se dava o relacionamento entre as diferentes organizações, chegou a dizer que sentia "que o MST e tudo o que ele representa estão sendo usados pelas outras organizações, já que elas é que se beneficiam dos recursos financeiros dos projetos”; já um técnico do IPÊ, falando sobre a mesma questão, dizia que era "necessário que os técnicos da COCAMP se capacitassem em elaboração de projetos e propostas, para que também a COCAMP e o MST pudessem captar recursos e ter maior autonomia para a execução de outras propostas ambientais, como por exemplo o cultivo de hortaliças orgânicas".

Essa assimetria entre as organizações com relação à autonomia para a tomada de decisões é um tema que merece bastante atenção. Por exemplo, ao escolher as áreas onde serão implantados os projetos, é inegável o maior poder de decisão do IPÊ. Estrategicamente, pode ser mais interessante para o MST implantar projetos ambientais em assentamentos que, do ponto de vista do IPÊ, não são os prioritários, uma vez que mesmo atuando de forma cooperativa, as organizações têm objetivos e estratégias diferentes.

Apesar da importância destas questões, o fato é que os projetos estão em andamento, e os incentivos são oferecidos para as famílias assentadas. O maior deles, segundo os dados da pesquisa, é a oferta de mudas de espécies florestais, seguida do apoio para o preparo do solo para o plantio. No caso da Gleba Ribeirão Bonito, as mudas são produzidas no viveiro do Parque e transportadas até o assentamento. $\mathrm{O}$ preparo do solo é feito com trator e implementos da Associação de Assentados da Gleba Ribeirão Bonito, o tratorista é um dos assentados, e o combustível é pago com recursos dos projetos, repassados para os assentados pelo IPÊ. Isso faz com que os custos de implantação de uma área de sistema agroflorestal sejam extremamente 
reduzidos para o assentado. A contrapartida do assentado é garantir o desenvolvimento das mudas, no que ainda é apoiado pelas organizações quando necessário. Por exemplo, quando ocorreu uma infestação de formigas (esse é um dos principais problemas técnicos para o desenvolvimento dos sistemas), foram oferecidos aos assentados, gratuitamente, pacotes de formicida ${ }^{27}$. Os cursos e seminários que acontecem na sede do Parque Estadual do Morro do Diabo também não têm nenhum custo para as famílias participantes. Elas recebem informações teóricas e práticas sobre agrofloresta, trocam experiências sobre os seus sistemas e aproveitam para passear, uma vez que as oportunidades de lazer são muito reduzidas. Além dos cursos, algumas vezes acontecem jogos de futebol, esporte muito popular entre os homens do assentamento, entre o time dos assentados e o time do Parque. Esta é mais uma forma encontrada para estreitar os laços de amizade entre o Assentamento e o Parque.

Enfim, o que se pode afirmar é que, a partir da formalização de uma aliança entre as diferentes organizações, são mobilizados recursos que passam a ser disponibilizados para os assentados através da intermediação das organizações. Os assentados, por sua vez, ao perceberem que participando dos projetos propostos por estas organizações podem auferir melhores resultados econômicos e não econômicos, tendem a se envolver cada vez mais com as atividades propostas. Passam a investir cada vez mais os recursos sobre os quais detém o controle (terra e trabalho) na transação com as organizações, com o intuito de conseguir as coisas que os interessam (recursos financeiros e conhecimento) e que estão sob o controle das organizações.

\footnotetext{
${ }^{27}$ Ver box 01 .
} 
Tendo verificado que é a existência de tal estrutura de incentivos que faz com que as famílias passem a incorporar nas suas atividades de manejo do lote as práticas de conservação da natureza, a próxima questão que deve ser enfrentada é a seguinte: essas transformações que estão ocorrendo são uma simples resposta racional aos incentivos oferecidos e estão fadadas a retroceder à medida que tais incentivos diminuem ou desaparecem ou, ao contrário, estão assumindo o status de uma nova regra de conduta, de uma nova instituição? 


\section{Box 01 - Exemplo de articulação de ação coletiva}

Estava em um seminário com os assentados e o problema das formigas foi um dos principais temas de discussão. Elas estavam ocasionando sérios danos às mudas mais novas. Iniciou-se, então, uma discussão sobre as formas de se combater as formigas. Dada a minha formação de engenheiro agrônomo ambientalista, pensei logo nas alternativas de manejo com as quais se poderia minimizar o problema sem o uso de agrotóxicos. Os assentados, contudo, após apresentarem diferentes formas de combate à formiga, logo concluíram que a melhor saída era a utilização de iscas formicidas, no que foram prontamente atendidos pelo IPÊ, que passou a fornecer o veneno para os assentados combaterem as invasoras. Compreender a lógica que estava por trás desta ação foi o desafio então. Perguntando para o coordenador do projeto ser ele não via uma incoerência entre conservação da natureza e o emprego de formicida, sua resposta foi bastante pragmática: "o nosso principal objetivo é proteger a floresta, o Parque. O uso de formicida neste estágio é muito importante para garantir que os assentados continuem a cuidar das árvores. A gente não pode arriscar". Feito o acordo com relação à questão técnica de combate às formigas, uma questão de ação coletiva passou a ser o centro das atenções. Um dos assentados mostrou que era necessário que todos se integrassem no esforço de combater as invasoras, pois se apenas alguns o fizessem, as formigas que estão no lote do vizinho que não faz o controle passam para o lote daquele que controla: "formiga não respeita cerca...ou todo mundo ajuda ou não adianta nada o esforço nosso". Mais uma vez, junto à uma questão técnica, a questão da coordenação da ação coletiva ganha uma dimensão muito importante. Após várias intervenções de outros assentados, ficou acordado que todos participariam do esforço de controle das invasoras. 


\section{3 - Conservação da Natureza: moda passageira ou uma nova instituição?}

Essa pergunta é fundamental para a discussão sobre o futuro dos assentamentos rurais e dos recursos naturais na região do Pontal do Paranapanema: a conservação da natureza é apenas a resposta racional que as famílias assentadas estão dando aos incentivos proporcionados pela rede de organizações ou está se transformando em uma nova instituição que pode balizar as ações futuras destas famílias, mesmo quando os incentivos não forem tão intensos ou deixarem de existir?

$\mathrm{O}$ que se pretendeu, portanto, foi buscar algumas evidências que possibilitem identificar como está se dando a incorporação, nos códigos de conduta que regem a vida social destas famílias, das transformações que vêm ocorrendo na forma como elas cuidam do lote e desempenham as suas atividades diárias. Vale ressaltar que, ao buscar resposta para esta questão, estamos pensando naquele tipo de instituição que North (1990) define como instituições informais, ou seja, elas não estão escritas ou formalizadas em leis ou estatutos, mas são incorporadas pelos atores de forma que têm o poder de determinar os tipos de comportamento socialmente aceitos na comunidade.

Ao concordar com as proposições de Bicchieri (1997), para quem as regras surgem nos pequenos grupos para depois serem difundidas em outros grupos maiores, podemos afirmar que está em curso um processo de construção de uma nova regra relacionada às formas como devem proceder as famílias assentadas em um lote de reforma agrária que está próximo a uma área de preservação ambiental. Nas entrevistas com as famílias, é recorrente a referência ao período 
anterior ao início dos trabalhos ambientais como sendo um momento em que não havia informações disponíveis que permitissem que elas pudessem desenvolver práticas ambientalmente mais apropriadas. Portanto, segundo as famílias entrevistadas, após tomarem contato com as informações sobre a importância da conservação da natureza e do trabalho amplo que vem sendo realizado na região do Pontal do Paranapanema, elas passaram a se preocupar verdadeiramente com a conservação ambiental e tiveram a chance de ampliar o seu poder de tomar decisões.

Vejamos um exemplo emblemático desta incorporação gradual da preocupação com a questão ambiental. O jornal Folha de São Paulo, em nota do dia 7 de junho de 2001, na página 11, informa que um protesto contra o atropelamento de animais bloqueou a estrada que atravessa o Parque Estadual do Morro do Diabo. Esta é a notícia na íntegra: "Em protesto contra o atropelamento de animais do Parque Estadual do Morro do Diabo, o MST bloqueou ontem, por quatro horas, a rodovia Arlindo Bétio (SP-613), que liga Teodoro Sampaio a Euclides da Cunha, no Pontal do Paranapanema. A rodovia corta o parque num trecho de $16 \mathrm{~km}$. Eles exibiram o crânio de uma onçapintada e o corpo de um cachorro do mato que teriam sido atropelados no local. Eles exigem a construção de túneis e alambrados para proteger os bichos. Segundo o MST, cercar de 300 pessoas participaram do protesto.

Os sem-terra pegaram carona no movimento idealizado pelo IPÊ ( Instituto de Pesquisas Ecológicas), uma ONG que realiza projetos ambientais no Parque. No fórum de Teodoro Sampaio tramita a ação que pede a construção de 
alambrados e túneis na estrada. Entre 1990 e 2000, 182 animais teriam morrido atropelados".

Esta ação coletiva mostra claramente a incorporação da preocupação com a conservação da natureza por parte de um grupo de participantes do MST assentado na região. As mesmas famílias que constituíam uma ameaça há pouco tempo atrás, hoje estão bloqueando uma estrada para pressionar as autoridades competentes a resolverem um problema que passou a ser também deste grupo de pessoas. Quando se lembra do trabalho de Cullen Jr. (1997), que apontava o verdadeiro desastre, do ponto de vista da conservação ambiental, que era o assentamento de famílias próximo a fragmentos florestais, a sensação ao ler uma notícia como essa é de perplexidade. Afinal, são os potenciais "inimigos da conservação" 28 que agora estão fazendo "barulho" para contribuir para a conservação ambiental da região do Pontal.

Obviamente, uma manifestação deste tipo não quer dizer que de uma hora para outra os assentados do Pontal se transformaram nos "guardiões da natureza". Ela ajuda, contudo, a entender como as relações de confiança que se estabelecem entre os diferentes atores têm a capacidade de mobilizá-los para as mais diferentes ações. Quando se analisa a fundo o que aconteceu neste episódio, fica evidente que a articulação anterior à manifestação foi pensada pela rede de organizações, cada uma avaliando o que poderia ganhar ou perder com a realização da ação. Ganha o MST, por associar à sua imagem a preocupação com

\footnotetext{
28 Os sem-terra/assentados são genericamente considerados grandes devastadores do meio ambiente, o que muitas vezes se justifica, como mostrou o relatório do Partido dos Trabalhadores sobre a devastação ambiental na Amazônia que, infelizmente, não foi levado a sério. A direção do MST e do próprio PT optaram por desqualificar o relatório, perdendo uma oportunidade valiosa de ampliar o debate sobre os rumos do desenvolvimento na região amazônica e o futuro dos assentamentos. Ao invés de tentar entender os motivos pelos quais os assentados adotam um determinado arcabouço de
} 
a questão ambiental. Ganha o IPÊ, e em última instância a natureza, pois com um grupo de pressão trazendo à tona o problema, ele assume novas dimensões, podendo inclusive ser objeto de maior atençãodos órgãos competentes.

De qualquer forma, o interessante é notar que a participação dos assentados se deu de forma expressiva. Se fossem apenas sem-terra acampados, que pela própria condição de não estarem ainda assentados em um pedaço de chão podem despender mais tempo em atividades de mobilização, poderia se pensar que era apenas mais um grupo atendendo ao chamado da direção do Movimento. Mas, ao contrário, foram as famílias assentadas que participaram da mobilização. Elas deixaram os seus afazeres diários e disponibilizaram uma parte do seu tempo e esforço para uma ação coletiva que, diretamente, não traria nenhum retorno para elas. O que pode explicar tal atitude é que elas já perceberam que a relação que estabeleceram com a conservação da natureza, através da participação nas atividades da rede de organizações, é vantajosa para todos.

Outra evidência que mostra a ampliação da preocupação com a conservação ambiental na região do Pontal do Paranapanema é a realização de Seminários sobre o tema que ocorrem com regularidade. Notícia veiculada pela Agência Estado, em 8 de março de 2001, mostra a articulação regional em torno de uma proposta de desenvolvimento sustentável para a região, com a incorporação dos mais diferentes atores sociais, de assentados a fazendeiros, de organizações não governamentais e estatais. O workshop "Econegociação: um Pontal bom para todos" ocorreu nos dias 9 e 10 de março de 2001 e teve como objetivo ampliar a discussão sobre o futuro da região. Nas palavras da presidente do IPÊ, Suzana

técnicas que implica em maior devastação ambiental e buscar alternativas a tal modelo, tanto o PT quanto o MST preferiram ignorar o conteúdo do relatório, classificando-o de tendencioso. 
Machado Pádua: “...o Pontal pode vir a se tornar um modelo de desenvolvimento sustentável, que contemple prioridades sociais e ambientais sem perder de vista os objetivos específicos de cada grupo".

A realização deste workshop aponta para dois aspectos muito interessantes. O primeiro deles é a ampliação e a incorporação de múltiplos atores sociais na rede de organizações e pessoas preocupadas em promover outro padrão de desenvolvimento na região do Pontal que incorpore definitivamente a conservação ambiental.

O segundo aspecto é quanto à credibilidade que ganham os projetos de conservação ambiental ao serem apoiados por organizações internacionais como, neste exemplo, a UNESCO. Tendo estas organizações incorporadas à rede que promove os projetos, estes ganham maior credibilidade junto ao público alvo das ações, que percebem que os seus esforços são reconhecidos em âmbito muito mais amplo que o regional. Uma lição que pode ser tirada deste evento é a importância da articulação de diversas organizações e em diversas esferas de atuação, desde a local (no próprio assentamento) até a mundial (na parceria com um organismo internacional). A idéia de fazer parte de um movimento muito maior, que extrapola os limites do local e se amplia até níveis internacionais, tem um efeito mobilizador extremamente importante para o engajamento dos atores sociais nos projetos ambientais e para a incorporação de atitudes conservacionistas nas regras de conduta que regem a interação social.

Estas considerações apenas apontam para um processo que está em curso, que já se iniciou, mas sobre o qual ainda não é possível fazer afirmações precisas quanto às perspectivas de futuro. O que se pode afirmar é que é necessária, por 
parte das organizações, uma postura de intervenção que garanta a continuidade do processo, para que através da prática constante de ações pautadas por uma nova forma de convívio com a natureza os atores passem a assumir tais ações como uma nova postura. Essa possibilidade de criação de novas instituições (formais e informais) ${ }^{29}$ deve ser entendida pelas organizações como um dos seus principais objetivos.

Por um lado, a criação de instituições informais pressupõe que, através da relação entre os atores, seja criada uma determinada estrutura de constrangimento que vai delimitar e orientar as ações de todos os atores. Parece que os trabalhos considerados como de educação ambiental e extensão agroflorestal se pautam exatamente pela criação deste tipo de instituição, de caráter eminentemente informal. Um dos resultados deste esforço foi a criação de um Coletivo de Agroecologia do MST, um grupo que se reúne periodicamente para discutir propostas de agroecologia adaptadas à situação dos assentamentos do Pontal do Paranapanema. Participam de tal grupo assentados e lideranças do MST, que buscam maiores informações sobre práticas agroecológicas de produção, como o cultivo orgânico de hortaliças, plantas medicinais e adubação verde.

Contudo, a preocupação com a continuidade do processo leva, também, à necessidade de criação de instituições formais. Desse ponto de vista, temos como principal protagonista o ITESP, que é a organização que tem o maior potencial de intervenção junto aos assentamentos, quer seja pela capacidade instalada (número

\footnotetext{
29 North (1990) faz uma distinção entre instituições formais e informais. Para ele, ambas têm grande importância na definição dos limites das ações dos atores. Por instituições informais entende-se os códigos de conduta, os costumes e as normas não escritas que regem a interação social. Já as instituições formais se identificam com as leis, as normas ou programas que passam por um processo de constituição formal. A importância de cada um destes tipos de instituição é muito relativo. Muitas vezes, uma instituição informal pode ter maior poder de constrangimento do que a lei. Neste estudo
} 
de técnicos, veículos, relação técnico/assentado, entre outros) desta organização estatal, quer seja pela legitimidade da sua atuação na região, uma vez que é a organização responsável pela condução do processo de reforma agrária na região. O que se verifica é a vontade, por parte da direção desta organização, de incorporar a preocupação com a conservação ambiental nos trabalhos que desenvolve. Isso pode ser verificado através das ações que vem desenvolvendo, como o Plano Pontal Verde (Plano de Recuperação Ambiental nos Assentamentos do Pontal do Paranapanema) e a preocupação em capacitar os seus quadros em técnicas agroecológicas, como agricultura orgânica e sistemas agroflorestais.

Contudo, verifica-se ainda uma certa dificuldade na incorporação do ITESP na rede de organizações, o que define um paradoxo que deve ser enfrentado com a máxima urgência. Ora, se o ITESP é a organização com o maior potencial de atuação junto às famílias assentadas, e é também a organização com a maior capacidade de influenciar a formulação de políticas públicas para os assentamentos no estado de São Paulo, porque ele não está mais integrado nesta rede? Quais os fatores que inibem a sua efetiva incorporação aos trabalhos desenvolvidos?

Mais uma vez, encontramos nas relações de confiança entre os atores os indícios que respondem estas perguntas. A relação que se construiu entre o IPÊ e os assentados e suas lideranças é muito diferente daquela que se construiu entre o IPÊ e o ITESP e entre o ITESP e os assentados e suas lideranças. Pela própria característica dos atores, essa dificuldade pode ser entendida. Por um lado, o IPÊ,

foi possível perceber a importância de ambas, que devem ser levadas em consideração pelas organizações que atuam na região. 
circunscrito no universo das organizações não governamentais, que têm uma dinâmica de trabalho muito mais ágil e pragmática, sem as amarras que as organizações governamentais enfrentam diariamente, encontra dificuldades em estabelecer uma verdadeira parceria com o ITESP. Existe uma relação de apoio mútuo, mas que ainda não se traduziu efetivamente em projetos cooperativos. Pode-se afirmar que a interação entre essas duas organizações, com características bem diferenciadas, ainda não atingiu seu pleno potencial. Contudo, verificou-se, também, um desejo premente, de ambos os lados, de que tal interação se torne mais estreita e se transforme em novos projetos de intervenção. De outro lado, como em muitos momentos MST e ITESP estabelecem uma relação de conflito entre si, a construção de uma interação de maior confiança mútua se torna mais difícil. Um exemplo disso são as ocupações do escritório do ITESP pelos militantes do MST em Teodoro Sampaio. Como construir uma relação de confiança se, de repente, uma das partes tem o seu escritório ocupado pelos integrantes da outra organização quando o crédito agrícola demora demais a ficar disponível para os assentados?

Assim, esse processo exige ainda muita negociação e disposição das partes em entender a postura das outras organizações e encontrar os pontos de convergência, para que se possa efetivamente construir um novo arcabouço institucional que permita que os assentamentos passem a desenvolver projetos que tenham como foco a melhoria da qualidade de vida das famílias. Talvez esse seja o principal ponto de convergência, e a utilização de espaços coletivos, como foi o workshop citado anteriormente, seja um dos caminhos mais promissores. 
Conclui-se, portanto, que mais do que um simples modismo, a preocupação com a questão ambiental está se tornando uma nova instituição na região do Pontal do Paranapanema. Os assentados demonstram maior envolvimento com a questão (como verificou-se com os assentados da Gleba Ribeirão Bonito), os organismos governamentais assumem a sua responsabilidade e se preparam para atuar de forma mais intensa (como é o caso do ITESP), as lideranças dos assentados incorporam tal problemática ao seu discurso e passam a apoiar qualquer atividade que tenham como foco a questão ambiental e as organizações ambientalistas continuam a articular apoio para os seus projetos.

A criação, no final de 2000, de uma Promotoria de Meio Ambiente por Ecossistema no Pontal do Paranapanema é mais um indício da incorporação da temática ambiental na região. A Promotoria, que funciona em caráter experimental há mais de um ano, é considerada, pelas organizações ambientalistas que atuam na região, um significativo avanço no enfrentamento de questões problemáticas do ponto de vista da conservação da natureza, como a invasão de posseiros em áreas de preservação ambiental. 


\section{7- CONCLUSÕES}

Após a apresentação das evidências empíricas coletadas ao longo das atividades de campo, conclui-se que a hipótese, segundo a qual a existência de uma estrutura de incentivos dada pela ação de uma rede de trabalho que envolve organizações ambientalistas não governamentais, organismos estatais de preservação ambiental, cooperativa de assentados, universidades e movimento social, está levando as famílias de agricultores assentadas a estabelecer novas formas de relacionamento com a natureza, foi amplamente corroborada.

A corroboração de tal hipótese, contudo, levanta uma nova questão extremamente importante, uma vez que ao se identificar a relação entre a transformação das práticas dos assentados e a estrutura de incentivos disponibilizada pela rede de organizações, surge a seguinte pergunta: como se dará a continuidade do processo, tendo em vista que os projetos em andamento têm prazo determinado para terminar? Ou melhor, como se garante que, ao diminuírem ou acabarem os incentivos disponibilizados para as famílias, elas ainda continuarão a desenvolver ações que levem em consideração a conservação da natureza? Algumas pistas para responder essa questão foram apresentadas anteriormente, ainda que não tenha sido possível apontar conclusões definitivas.

A primeira delas é a criação de instituições informais duradouras, que acabam por constranger aquelas ações consideradas impróprias do ponto de vista da conservação dos recursos naturais. Como ensina Bicchieri (1997), as pessoas podem desenvolver sanções internas como resultado do processo de controle social que as instituições exercem sobre as ações individuais, ou seja, através da experimentação 
de novas atitudes e normas de conduta, as pessoas acabam por desenvolver um determinado grau de envolvimento com a questão da conservação ambiental que prescinda dos incentivos que estão sendo, até o momento, disponibilizado para elas. Existiria, neste nível, um grau de constrangimento tal que impediria a pessoa de tomar determinadas atitudes que não fossem condizentes com os padrões de atitude esperados pelas outras pessoas.

A outra pista é a necessidade de incorporação cada vez mais intensa do Estado no trato da questão ambiental nos assentamentos. Isso já vem ocorrendo, e o cenário que se vislumbra parece bastante promissor, principalmente pela determinação do ITESP em capacitar seus técnicos em conhecimento agroecológico e desenvolver projetos direcionados para a sustentabilidade dos assentamentos rurais na região, aliando ao desenvolvimento socioeconômico das famílias a preocupação com a conservação da natureza. O Estado, portanto, não pode negligenciar, ao desenvolver tais projetos, dos aspectos econômicos que movem a ação coletiva nos assentamentos. A idéia de que apenas com palestras de capacitação e educação ambiental se consegue transformar profundamente as práticas dos agricultores parece estar um tanto quanto equivocada, uma vez que os incentivos econômicos se mostraram, ao longo da pesquisa, fundamentais para estimular os agricultores a se engajarem em uma ação coletiva que tem na conservação da natureza um dos seus principais elementos.

Porém, é necessário que se abram novos canais de comunicação entre os diferentes atores que, de uma forma ou de outro, estão ligados à questão do desenvolvimento sustentável na região. Atividades como seminários, workshops e grupos de discussão e trabalho conjunto podem se constituir como verdadeiros 
espaços de construção de um futuro mais sustentável para a região. É nessas arenas (Hanningan, 1995) que os diferentes atores poderão identificar os pontos divergentes entre si, bem como aqueles que convergem para o mesmo rumo.

A incorporação de mecanismos de mercado também deve ser entendida como uma das principais formas de se garantir a continuidade do processo que está em curso nos assentamentos da região. É cada vez maior a necessidade de introduzir as famílias assentadas na dinâmica dos mercados, compartilhando cada vez mais com elas a responsabilidade pelo sucesso das ações voltadas ao desenvolvimento sustentável da região.

Os Mecanismos de Desenvolvimento Limpo estão sendo entendidos como uma importante oportunidade para os assentamentos da região. Ora, uma região que já foi coberta com uma exuberante floresta tem, segundo os ambientalistas, todas as condições para o desenvolvimento de um projeto amplo de seqüestro de carbono. Em um projeto como este, os assentados poderiam produzir florestas que seriam utilizadas como "sumidouros de carbono" e que seriam financiadas através da comercialização de cotas de carbono.

Mais uma vez foi possível assistir uma interessante disputa na arena em que atuam os diferentes atores sociais, uma vez que os militantes do MST vêem com muita desconfiança a incorporação dos assentamentos no mundo capitalista que se abre com essa possibilidade. Em conversa recente com um dos técnicos do IPÊ que está coordenando a articulação de um projeto que pretende estudar a viabilidade da incorporação de tal estratégia para a conservação ambiental na região do Pontal, foi possível perceber a tensão entre os interesses dos ambientalistas, que vêm nesta possibilidade uma forma de ampliar o alcance das ações conservacionistas na região, 
e os interesses dos militantes do MST, que estão receosos e apreensivos quanto à proposta. Foi possível ainda corroborar a afirmação de que existe uma dificuldade séria de incorporação do ITESP nesta rede de organizações. Na articulação deste projeto o ITESP não foi incorporado, o que faz com que as relações entre estas organizações continue no estágio de desarticulação identificado desde o início desta pesquisa.

De qualquer forma, a utilização dos mecanismos de mercado pode ser uma interessante alternativa para garantir a continuidade do processo de criação de uma regra de conduta nos assentamentos que tenha na conservação da natureza um dos seus principais pressupostos. Contudo, o que a pesquisa demonstrou é que o sucesso das intervenções voltadas às práticas agroflorestais dependem de dois principais fatores: a) a existência de uma estrutura de incentivos bem definida que possa sinalizar para os indivíduos que a adoção de estratégias de conservação é a mais apropriada e b) a existência de uma relação de confiança entre os diferentes atores que sinaliza para as partes que é possível adotar as estratégias de cooperação e, assim, coordenar a ação coletiva.

Portanto, o desafio que se coloca para as organizações que estão inseridas na discussão da construção de um modelo de desenvolvimento alternativo para a região do Pontal do Paranapanema é como conciliar estratégias que, por um lado ampliem o alcance das ações e, por outro lado, garantam que os atores continuarão a manter as relações de confiança que caracterizam os sucessos das propostas em andamento na região.

Ao que parece, o caminho mais promissor para a construção de um novo modelo de desenvolvimento regional passa necessariamente pela participação das 
comunidades assentadas na definição dos rumos deste desenvolvimento. A criação e o fortalecimento de arenas de discussão é fundamental para aglutinar as diferentes organizações, os diferentes pensamentos a respeito do futuro da região para que, a partir das diferenças e dos conflitos, sejam construídos os caminhos que levem, por um lado, ao desenvolvimento pleno das populações que habitam a região do Pontal e, por outro lado, garantam a conservação da natureza.

Ao que tudo indica, esses caminhos já estão sendo trilhados e as forças transformadoras já estão em movimento, acumulando aquele tipo de capital (o capital social) que pode fazer a diferença no futuro do desenvolvimento desta região. 


\title{
8- BIBLIOGRAFIA
}

\begin{abstract}
ABRAMOVAY, Ricardo (2000) - "O capital social dos territórios: repensando o desenvolvimento rural" - Economia Aplicada - vol. IV número 2:379-397 abril/junho.
\end{abstract}

ABRAMOVAY, Ricardo (2001) - "Desenvolvimento e instituições: a importância da explicação histórica". Publicado em ARBIX, Glauco; ZILBOVICIUS, Mauro e ABRAMOVAY, Ricardo (2001) - Razões e ficções do desenvolvimento. São Paulo: UNESP/EDUSP - pp. 165-177.

ABRAMOVAY, Ricardo (2002) - "Obstáculos ao desenvolvimento territorial". Gazeta Mercantil 13/03/02 - p. A2

AXELROD, Robert (1997) - The Complexity of Cooperation - Agent-Based Models of Competition and Collaboration - Princeton Studies in Complexity - Princeton University Press.

BERGER, Peter L. e LUCKMANN, Thomas (1999) - A Construção Social da Realidade: tratado de sociologia do conhecimento. Tradução de Floriano de Souza Fernandes. Petrópolis, Vozes, 1985. 18 ${ }^{\mathrm{a}}$ Edição

BICCHIERI, Cristina (1997) - “Learning to Cooperate”. In Bicchieri, C., Jeffrey, R. e Skyrms B. (eds.) The Dynamics of Norms. Cambridge: Cambridge University Press, pp. 17-46.

CASTELLS, Manuel (1997) - The Information Age: economy, society and culture. V.2 - The power of identity. Blackwell Publishers. 
COLEMAN, James (1990) - Foundations of Social Theory. Cambridge: The Bellknap Press of Harvard University Press.

CULLEN Jr., Laury (1997) - Hunting and biodiversity in Atlantic Forest Fragments, São Paulo, Brazil. Dissertação de Mestrado. University of Florida. 98p.

CULLEN JR.,L \& VALLADARES-PADUA,C. (1999) - Pontal do Paranapanema: reforma agrária com conservação da natureza - (mimeo.)

CUNHA, L. (1993) Conflitos entre populações humanas em Unidades de Conservação em Mata Atlântica. São Paulo, NUPAUB/USP. California Press, Berkeley, 482.

DEAN, Warren (1996) - A ferro e a fogo: a história da devastação da Mata Atlântica brasileira. São Paulo. Ed. Companhia das Letras.

EHLERS, Eduardo (1998/1999) - "Diversificação: um caminho para a sustentabilidade agrícola". In: Revista Debates Socioambientais. Ano IV - № 11 Nov/Fev.

FERNANDES, B.M. (1996) - MST: formação e territorialização. São Paulo: Hucitec, 1996

FERRARI LEITE, José (1981) - A ocupação do Pontal do Paranapanema. Volume 1. $1^{\text {a }}$ Edição. UNESP, Presidente Prudente.

HANNINGAN, John A. (1995) - Environmental sociology: a social construcionist perspective. London, Routledge.

HARDIN, G. (1968) - “The Tragedy of Commons”. Science 162:1243-8. 
HUNTER, Jr., M.L. (1996) - Fundamentals of Conservation Biology. Cambridge, Blackwell Science.

ITESP (1998) - Pontal Verde: Plano de Recuperação Ambiental nos Assentamentos do Pontal do Paranapanema. Nㅜ 2 (jul. 1998). São Paulo: ITESP. (Série Cadernos ITESP/Secretaria da Justiça e da Defesa da Cidadania).

ITESP (1998) - Retrato da Terra 97/98: Perfil Sócio-Econômico e Balanço da produção agropecuária nos assentamentos do Estado de São Paulo № 9 (dez. 1998). São Paulo: ITESP. (Série Cadernos ITESP/Secretaria da Justiça e da Defesa da Cidadania).

KAGEYAMA, P.Y. e GANDARA, F.B. (1993) - Dinâmica de populações de espécies arbóreas: implicações para o manejo e a conservação. III Simpósio de Ecossistemas da Costa Brasileira - Anais Acad.de Ciências do Est. de São Paulo. p $1-9$.

LATOUR, Bruno (2000) A Ciência em Ação: como seguir cientistas e engenheiros sociedade afora. São Paulo: Editora UNESP. Tradução de Ivone C. Benedetti.

METZGER, J.P. (1999) - Estrutura da Paisagem e Fragmentação: Análise Bibliográfica. Anais da Acad. Brasileira de Ciências 71 (3).

NAVARRO, Zander (1997) - "Sete teses equivocadas sobre as lutas sociais no campo, o MST e a reforma agrária". In: STÉDILE, J.P. (org). A reforma agrária e a luta do MST. Petrópolis: Vozes, 1997.

NORTH, Douglas C. (1990) - Institutions, Institutional Change and Economic Performance. Cambridge University Press. 
OLSON, Mancur. (1965/1971) - The Logic of Collective Action. Cambridge: Harvard University Press.

OSTROM, Elinor (1986) - Ann Agenda for the study of Institutions. Public Choice 48:3-25.

OSTROM, Elinor (1990) - Governing the Commons: the Evolution of Institutions for Collective Action. Cambridge: Cambridge University Press

PADUA,S.M. (1997) - 'Uma pesquisa em Educação Ambiental: A Conservação do mico-leão-preto (Leontopithecus chrysopygus)". In: Valladares-Padua, Bodmer, R.\& Cullen Jr.(Eds) Manejo e Conservação da Vida Silvestre no Brasil. $1^{\text {a }}$ Edição. Volume 1. MCT-CNPQ, Brasília.

PUTNAM, Robert (1993/1996) - Comunidade e democracia - A experiência da Itália moderna - Fundação Getúlio Vargas, Rio de Janeiro.

SEN, Amartya K. (2000) - Desenvolvimento como Liberdade. São Paulo: Companhia das Letras.

VALLADARES-PADUA et alli (1996) - Resgatando a Grande Reserva do Pontal do Paranapanema: reforma agrária e conservação da biodiversidade - (mimeo)

VEIGA, José Eli (1999) - “A face territorial do desenvolvimento”. Anais do 27ำ Encontro Nacional de Economia, Campinas, 12-15 de dezembro de 1999, volume II, pp.1301-1318.

WITT, U. (1989) - "The Evolution of Economic Institutions as a Propagation Process”. Public Choice, 62 (August), pp. 155-172. 


\section{9 - APÊNDICE}

\section{1 - Figuras}

Figura 01 - Seminário sobre Reforma Agrária e Agroecologia, realizado na sede do Parque Estadual do Morro do Diabo.

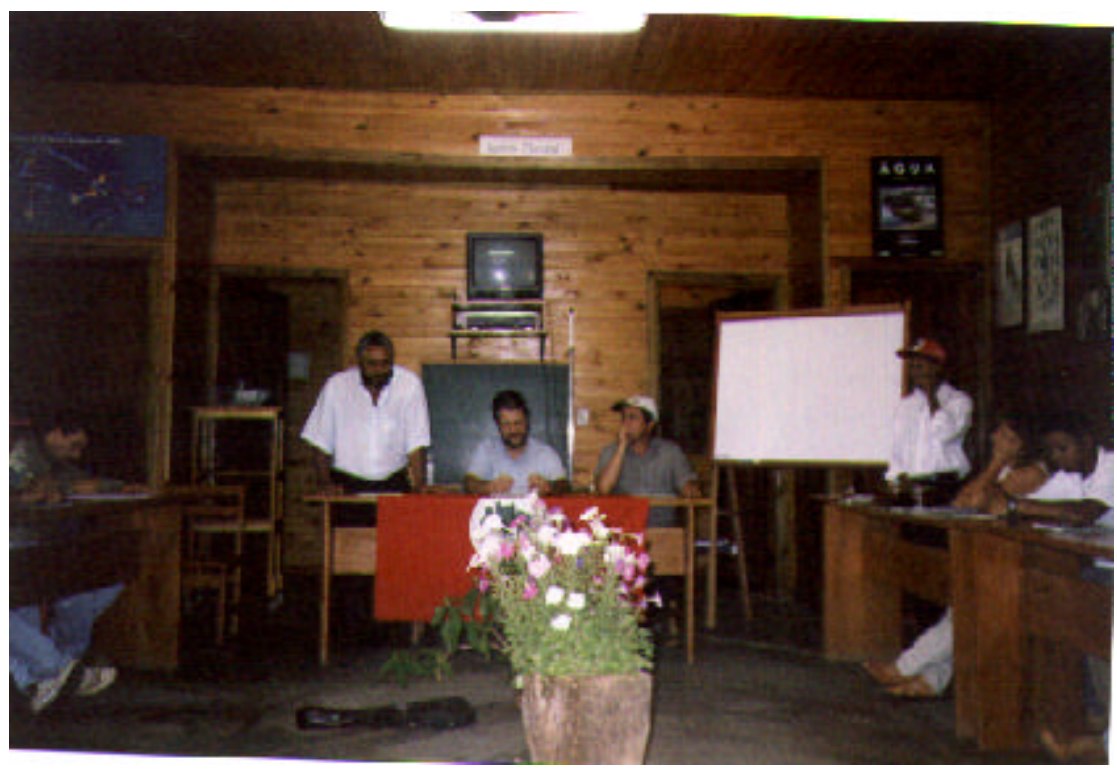

A foto acima mostra uma arena muito comum no Pontal do Paranapanema. Podemos identificar na mesa o pesquisador e diretor executivo de IPÊ, Claudio ValladaresPádua ao lado de Walmir Rodrigues Chaves, o Bill, então presidente da Cocamp.

Neste seminário foram discutidas alternativas agroecológicas para 0 desenvolvimento dos assentamentos rurais do Pontal. A participação de outras organizações não governamentais que atuam em projetos semelhantes, como a AS-PTA, representada neste seminário, é entendida como fundamental para ampliar o alcance das ações nos assentamentos, diversificando $\mathrm{o}$ enfoque da agroecologia. Como o IPE atua fundamentalmente na recuperação de florestas, a incorporação de outros atores que podem contribuir para a construção de novas propostas de produção sustentável, que garantam a melhoria da qualidade de vida das comunidades ao mesmo tempo em que garantem a manutenção da biodiversidade na região, é entendida como fundamental. A incorporação destes outros atores pode responder a uma demanda dos assentados, que são as alternativas produtivas com menos impacto ambiental, que não pode ser suprida diretamente pelo IPÊ. 
Assim, a forma encontrada para que tal demanda seja atendida é através do apoio para a troca de experiências com entidades que se dedicam a ações como, por exemplo, a agricultura orgânica. São mobilizados recursos da rede de organizações para a construção destes espaços coletivos de aprendizagem, que acabam também por definir os limites e o alcance da atuação de cada uma das organizações envolvidas com a temática socioambiental na região. 
Figura 02 - Trator dos assentados preparando o solo para a implantação de sistemas agroflorestais

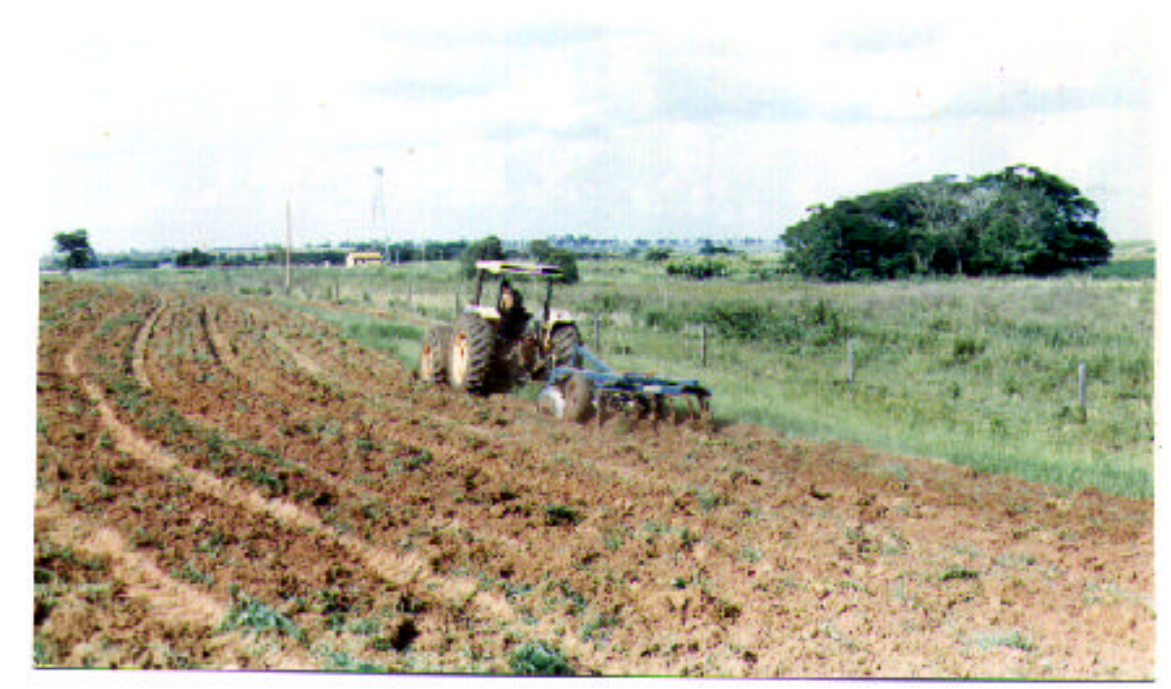

O preparo do solo é um dos incentivos oferecidos pela rede de organizações para as famílias assentadas. O tratorista é um dos assentados, o combustível é fornecido pelo IPE e o trator e os implementos pertencem à Associação de Assentados (para a compra de tratores e equipamentos agrícolas os assentados têm que se compor em associações). Assim, através desta parceria, os plantios de sistemas agroflorestais são implantados em faixas dos lotes das famílias, que se comprometem, então, a cuidar das mudas, controlando pragas e doenças. A maior dificuldade continua sendo com as formigas, que são controladas com o uso de venenos fornecidos pelo IPÊ para as famílias. A leitura que os técnicos do IPÊ têm dessa prática é bastante pragmática: "as mudas precisam crescer?". O contraponto a esse pensamento é elaborado por alguns técnicos da Cocamp: "como a gente pode falar de agroecologia se estimula os assentados a usarem venenos de multinacionais?” 
Figura 03 - Viveiro Agroflorestal do Parque Estadual do Morro do Diabo

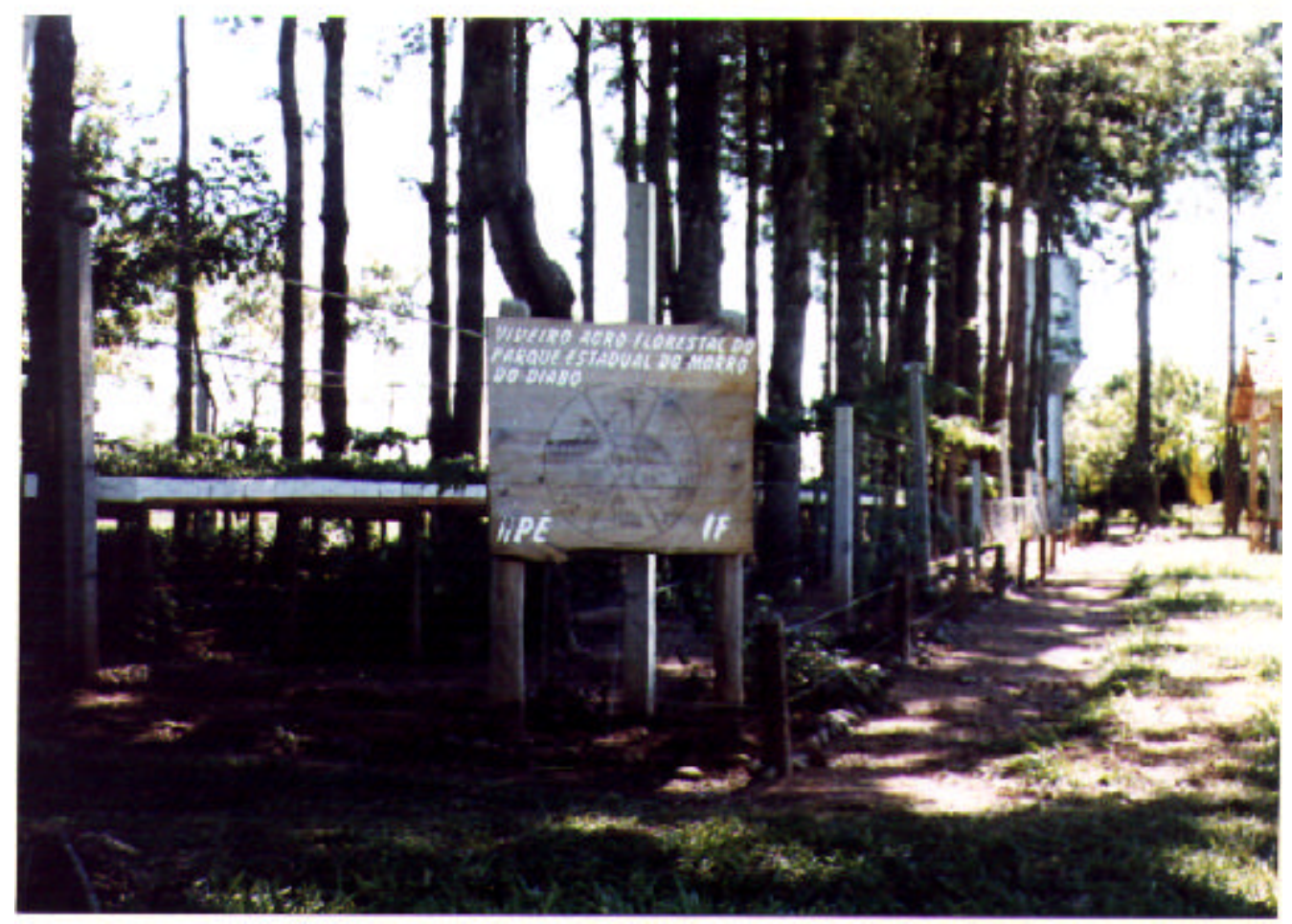

A estrutura de incentivos disponibilizada para as famílias assentadas conta ainda com um viveiro agroflorestal instalado na sede do Parque Estadual do Morro do Diabo. Isso demonstra a importância da articulação das diferentes organizações. A área do viveiro é cedida pelo Instituto Florestal, que também cede 4 funcionários para a manutenção das mudas. O IPÊ negociou com outras organizações o apoio financeiro para a instalação do viveiro, além de disponibilizar todos os conhecimentos técnicos necessários para a produção de mudas. Além disso, conseguiu recursos para reativar o laboratório de sementes do Parque, que tem papel fundamental na coleta, beneficiamento e coleta de sementes florestais regionais. As sementes são coletadas nas áreas do Parque e em outros fragmentos florestais da região e utilizadas para a produção das mudas que serão doadas para as famílias dos assentamentos rurais. Além desse papel de fornecedor de mudas para os assentamentos, o viveiro também tem a função de ensinar aos agricultores algumas práticas básicas de manejo agroflorestal. Durante os cursos realizados no Parque, é no viveiro que são realizadas as atividades práticas de aprendizagem, como pode ser visto nas fotos 04 e 05. 
Figuras 04 e 05 - Atividades práticas no viveiro do Parque
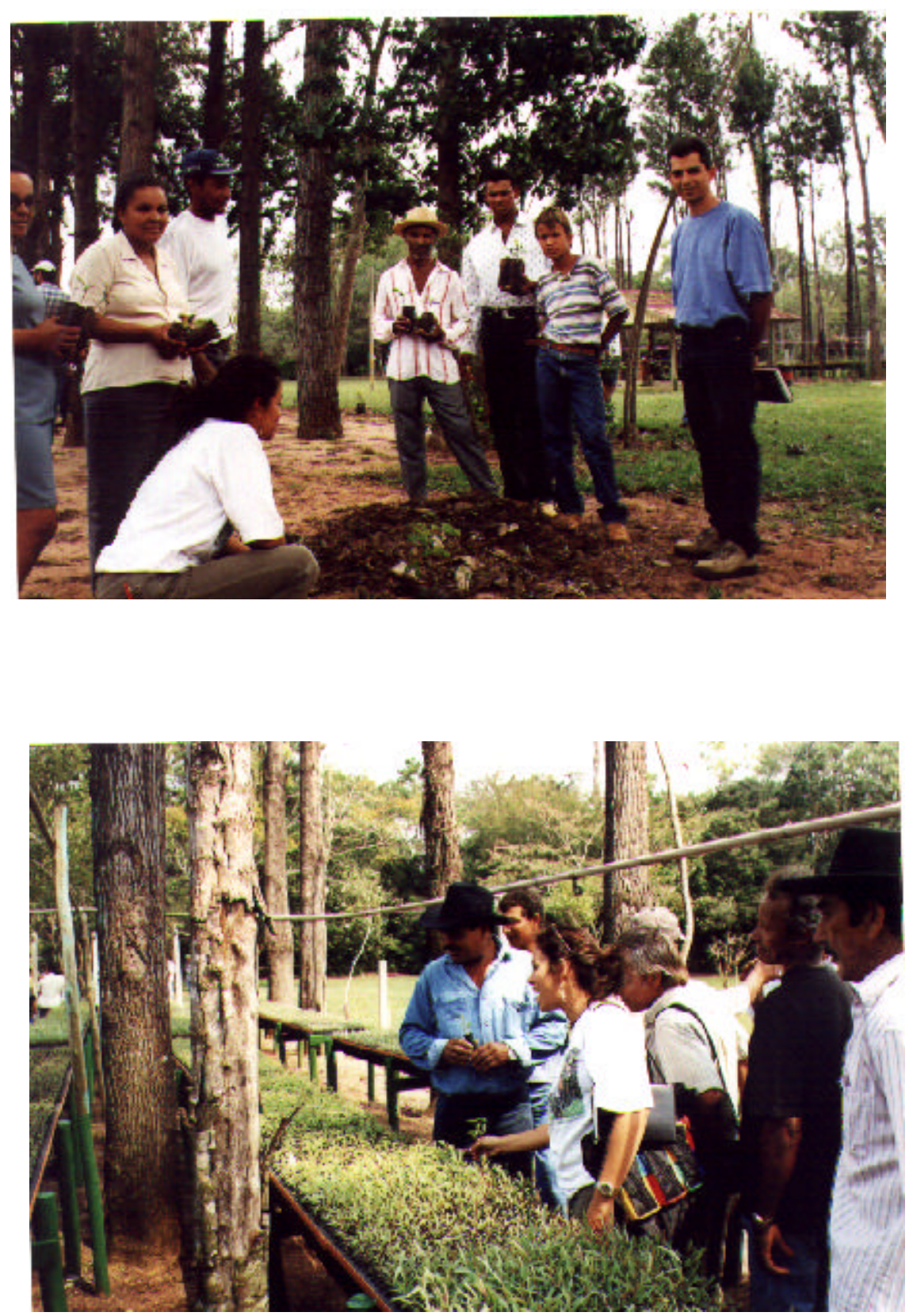
Figura 06 - Entrega de mudas agroflorestais nos assentamentos.

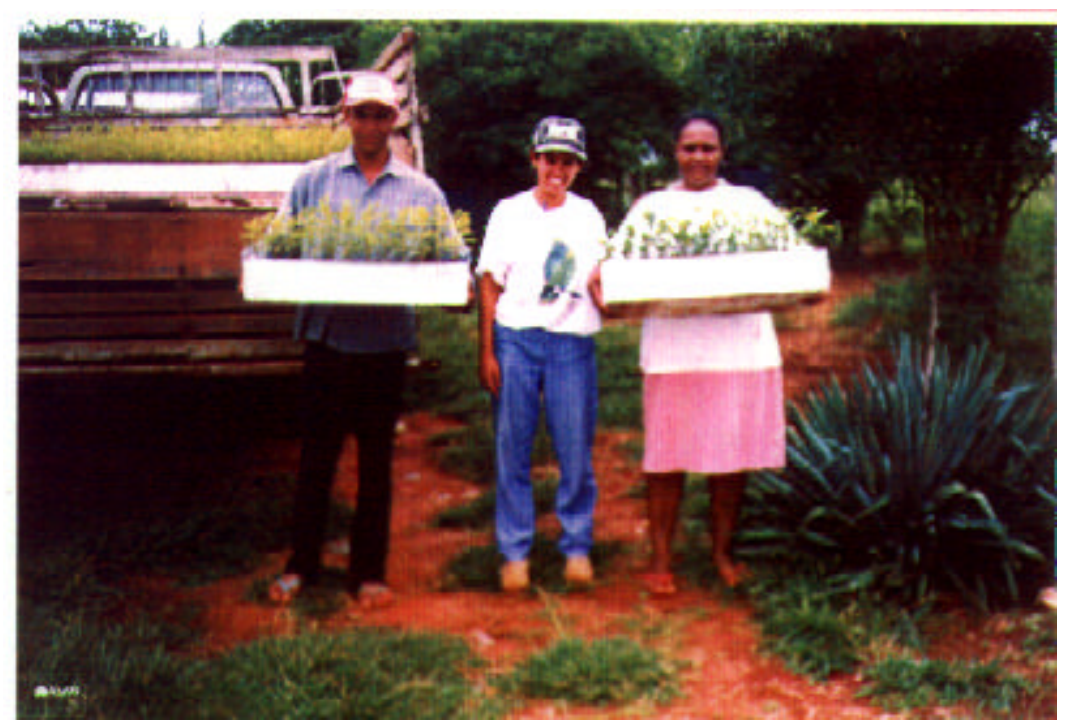

Quando as mudas produzidas no viveiro do Parque estão em idade de ir para o campo, a equipe do IPÊ, junto com funcionários do Instituto Florestal, fazem a entrega nos lotes das famílias assentadas. Como já foi exposto anteriormente, esse é um momento de intensa negociação entre as famílias e os técnicos, já que a demanda prioritária das famílias é por mudas de eucalipto, que crescem rápido e têm valor de mercado. Já os ambientalistas estimulam as famílias a receberem mudas de outras espécies, uma vez que o seu objetivo principal é aumentar a diversidade biológica. São feitos, então, vários acordos que acabam por garantir que ambas as partes se beneficiem dessa troca.

A doação direta de mudas, junto com o auxílio para o preparo do solo, é entendida pelas famílias como um dos principais estímulos que fizeram com que elas se incorporassem ao esforço de conservação da natureza que está sendo realizado no Pontal do Paranapanema. 
Figura 07 - Torneios de futebol na sede do Parque Estadual do Morro do Diabo.

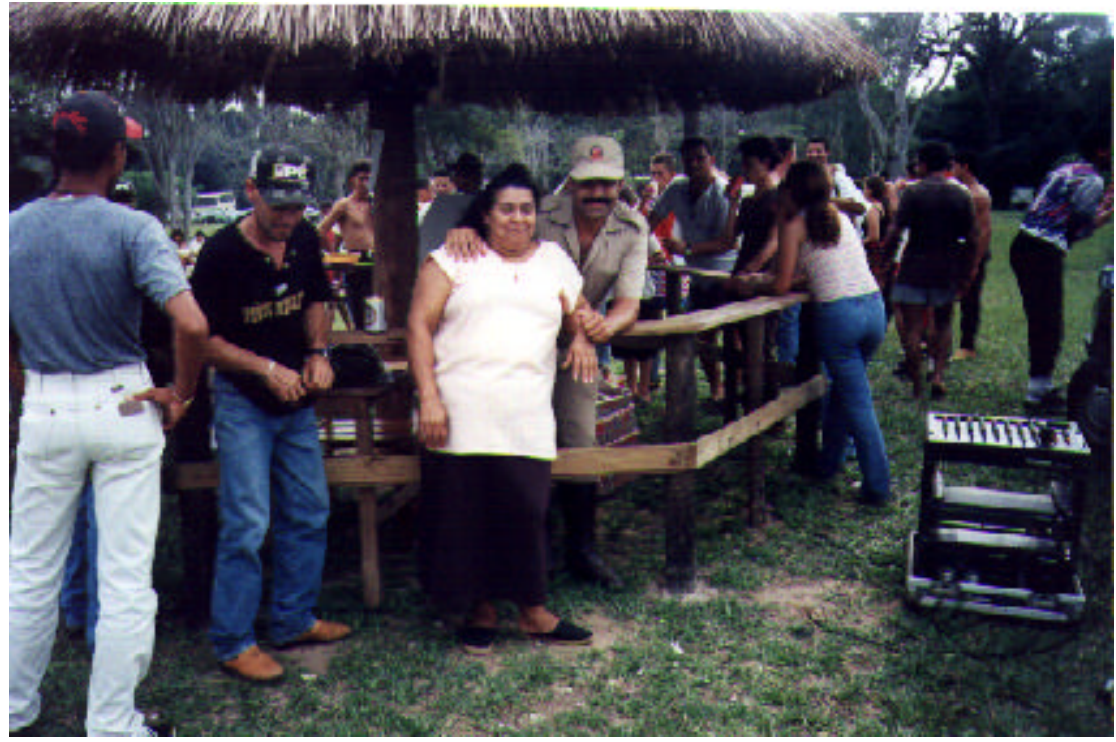

A estrutura de incentivos oferecida pela rede de organizações inclui ainda atividades de lazer para as famílias assentadas, como torneios de futebol na sede do Parque. Nos assentamentos, uma das formas de organização das famílias é em torno dos times de futebol, que disputam torneios e partidas amistosas com times de outros assentamentos. Percebendo a importância desta atividade na vida social das famílias, é estimulada a vinda dos times ao Parque. Enquanto os times disputam as partidas, as mulheres e crianças visitam as trilhas de educação ambiental e desfrutam de momentos de contato direto com a natureza exuberante do Parque. É também uma oportunidade para a integração dos guardas florestais com as famílias assentadas. Se num primeiro momento os guardas viam os assentados como um grupo que poderia causar danos ao Parque, hoje têm um contato mais direto e amistoso com essas famílias.

Nas entrevistas de campo o aspecto do lazer que é proporcionado nas visitas ao Parque foi destacado como um dos principais fatores que estimulam atitudes conservacionistas. "Depois de ver aquela beleza toda, a gente quer ter aquelas árvores todas no quintal da nossa casa!” - assim se referiu a Dona Maria, assentada na Gleba Ribeirão Bonito, sobre as visitas ao Parque. 
Figura 08 - Captura de onça no Pontal. Na foto está presente o presidente da COCAMP, Walmir Rodrigues Chaves, o Bil.



A foto acima mostra a primeira captura de onça feita pela equipe do IPÊ no Parque Estadual do Morro do Diabo. Quando da captura, uma das primeiras providências foi convidar o presidente da COCAMP para acompanhar todos os procedimentos realizados com o animal. A partir dessa experiência, foi possível para o Bil entender melhor o que a equipe de pesquisadores do IPÊ fazia quando "corria mato adentro atrás de bicho". Esse foi um dos momentos de interação mais interessantes entre os representantes da natureza e o representante dos assentados. Após essa experiência, o Bil não parou mais de falar, nas assembléias do movimento, da importância de preservar os animais e as plantas do Pontal.

$\mathrm{O}$ contraponto disso é a participação dos pesquisadores do IPÊ nas assembléias do MST. Nessas assembléias, os ambientalistas passam a entender melhor as demandas dos sem-terra, e assim também modificam a sua forma de entender a região.

Assim, através da interação constante, as organizações se influenciam mutuamente, o que faz com que nenhuma permaneça a mesma. Todas se modificam e modificam o sentido da sua ação. 
Figura 09 - Troca de experiências entre assentados na Gleba Ribeirão Bonito.

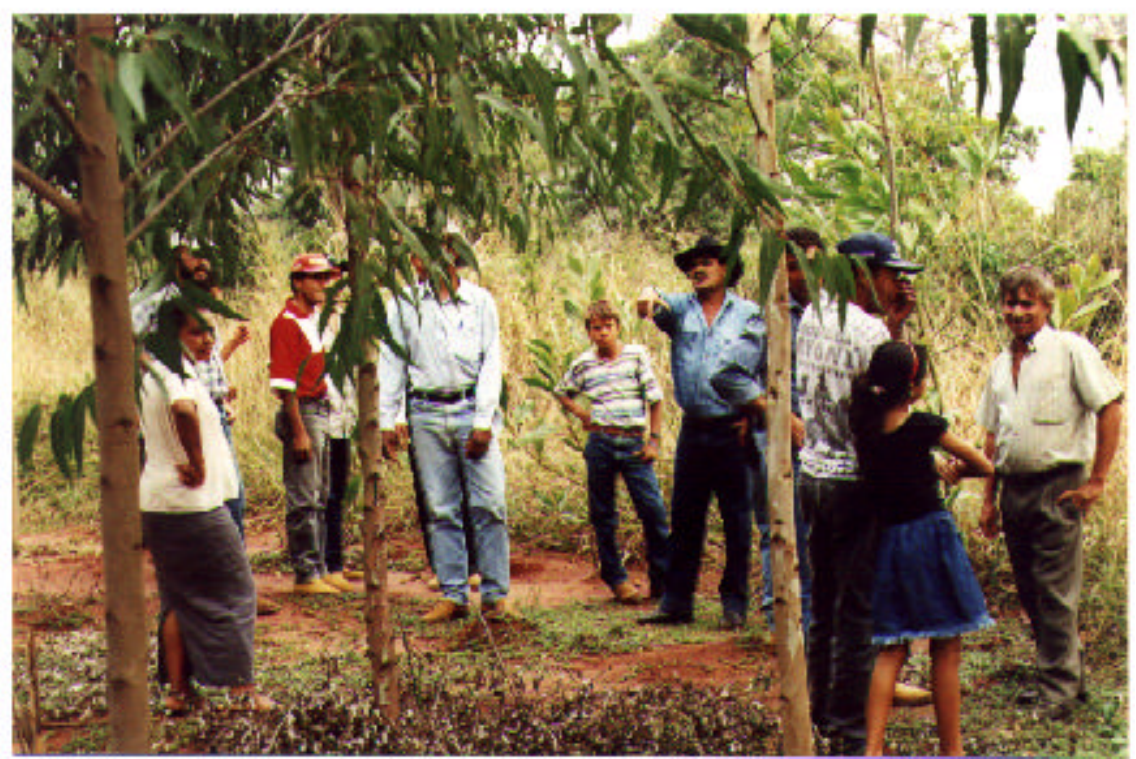

A experiência da Gleba Ribeirão Bonito tem sido compartilhada com outros assentamentos através de atividades como a retratada acima. Chamam a atenção dois aspectos principais nesta foto. O primeiro deles é a influência que a demonstração prática das atividades agroflorestais tem sobre os agricultores. $\mathrm{Na}$ foto acima, Miro, de camisa azul e chapéu, explica para os visitantes da Gleba Tucano, como vem conduzindo os seus sistemas agroflorestais e fala sobre os resultados que vem conseguindo com essa nova atividade. O espanto está nas falas dos visitantes: 'Mas o eucalipto não chupa a água das plantas? O milho vai bem embaixo dessas árvores?" A visita acaba rendendo um número expressivo de agricultores entusiasmados com as possibilidades de implantar esses sistemas nos seus lotes.

O segundo aspecto é com relação ao aumento da auto-estima dos agricultores, que agora servem de exemplo para os seus companheiros. Cada explicação é acompanhada de exclamações e perguntas entusiasmadas, e é fácil perceber a satisfação daquele que explica como conduzir os plantios, os principais cuidados com o solo, as expectativas de retornos financeiros. Cada vez mais essas famílias têm condições de decidir sobre o seu próprio futuro, de trilhar os caminhos que consideram os mais apropriados para a satisfação de suas necessidades. 
Figura 10 - Mostrando resultados para os parceiros na Gleba Ribeirão Bonito.

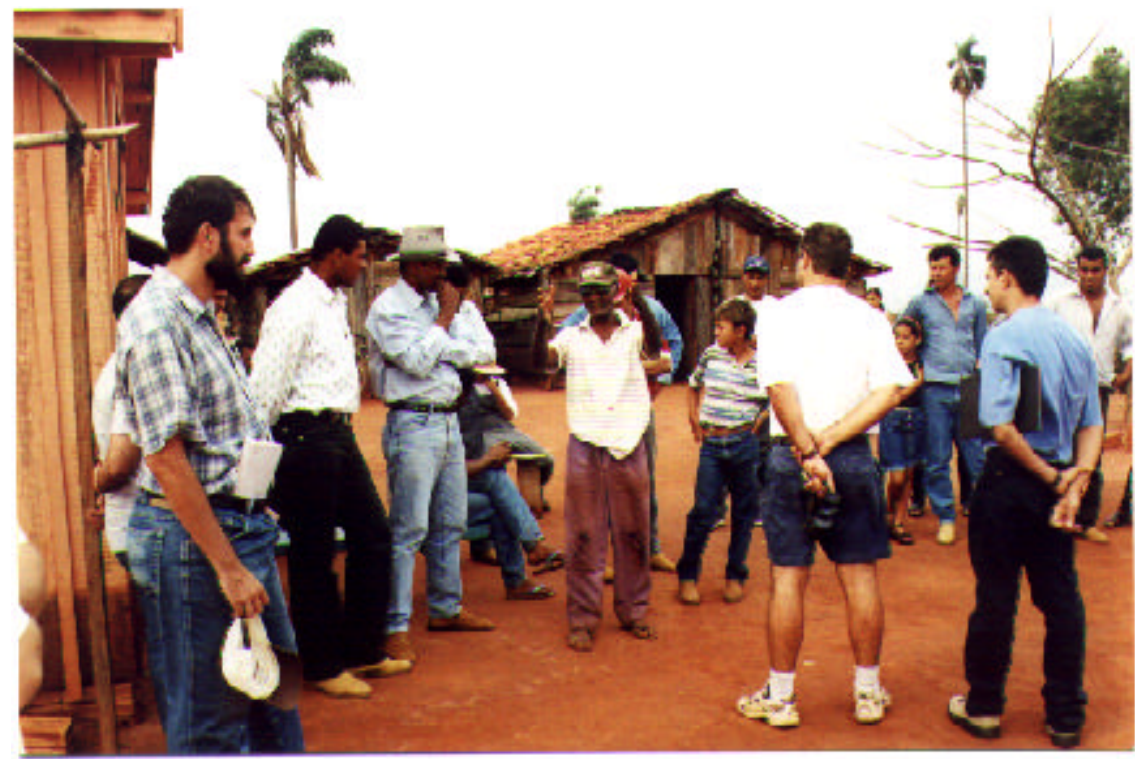

Esta foto foi tirada no mesmo evento de troca de experiências apresentado anteriormente. Destacamos, porém, um aspecto diferente, que é o que Latour chama de "encenação" na atividade científica.

Quando aconteceu esse evento de troca de experiências, um consultor do Ministério do Meio Ambiente estava avaliando um dos projetos do IPÊ. Esse consultor, que aparece na foto de camisa xadrez e boné branco na mão, foi convidado a participar da atividades na Gleba Ribeirão Bonito. O que está por trás deste convite?

Latour diria que este convite nada mais é do que uma forma dos pesquisadores do IPE apresentarem para um agente financiador os resultados do trabalho que desenvolvem. Ao levarem o consultor ao assentamento e deixá-lo ouvir os assentados falarem, os pesquisadores do IPE apostam na seriedade do seu trabalho, se expõem à crítica e ampliam a rede de contatos que poderá beneficiar os projetos no futuro. Mais do que um relatório de atividades, a visita no campo possibilita ao consultor apreciar a forma como estão sendo conduzidas as atividades e avaliar como a comunidade participa do processo. 
Figura 11 - Visitas aos lotes das famílias assentadas durante a pesquisa de campo.

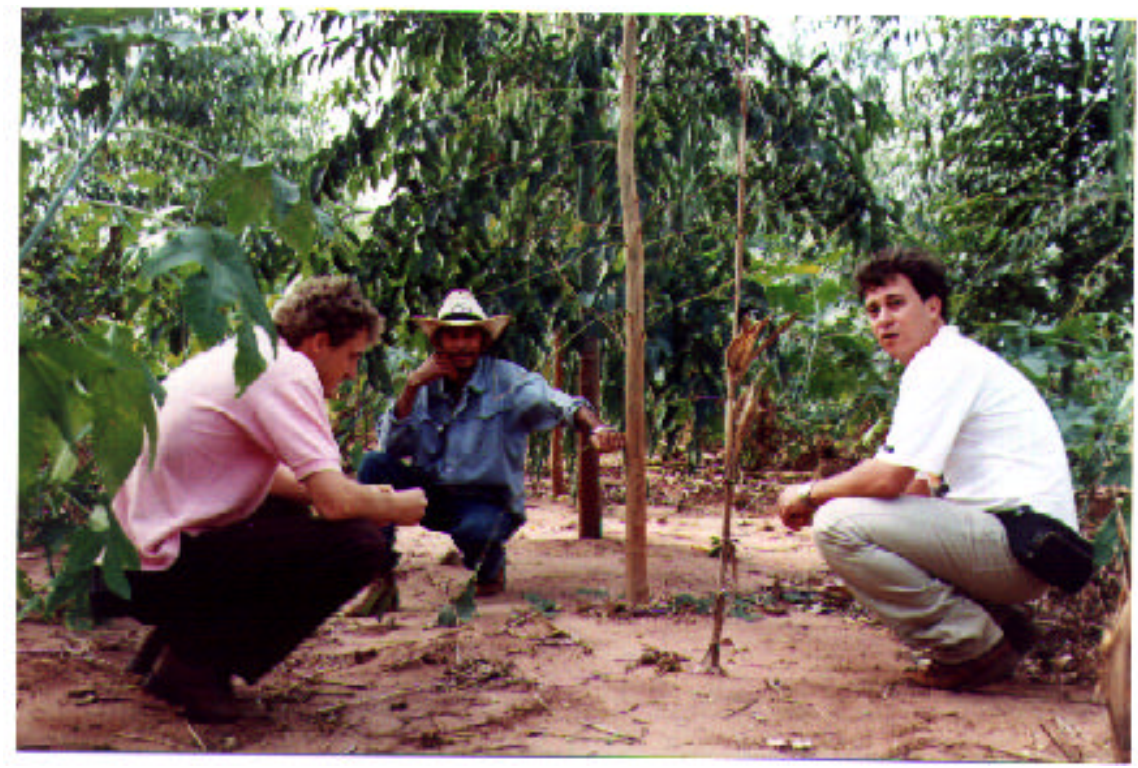

$\mathrm{Na}$ foto acima, o pesquisador (de camiseta branca) visita o sistema agroflorestal de um dos assentados da Gleba Ribeirão Bonito (de camisa azul) acompanhado de técnico da COCAMP. Nestas visitas de campo, além das entrevistas com as famílias, o "andar no lote, visitar os sistemas e conversar de forma descontraída" foram instrumentos de análise muito ricos.

A interação anterior do pesquisador com essas famílias permitiu que as atividades de investigação se transformassem em um espaço agradável de troca de experiências.

Muitas vezes, andando com os assentados no lote, aspectos que não haviam sido mencionados nas entrevistas, espaços mais formais, foram levantados e discutidos, tornando mais fácil a tarefa de desvendar a realidade. 
Figura 12 - Participação do pesquisador em seminários promovidos pelas organizações

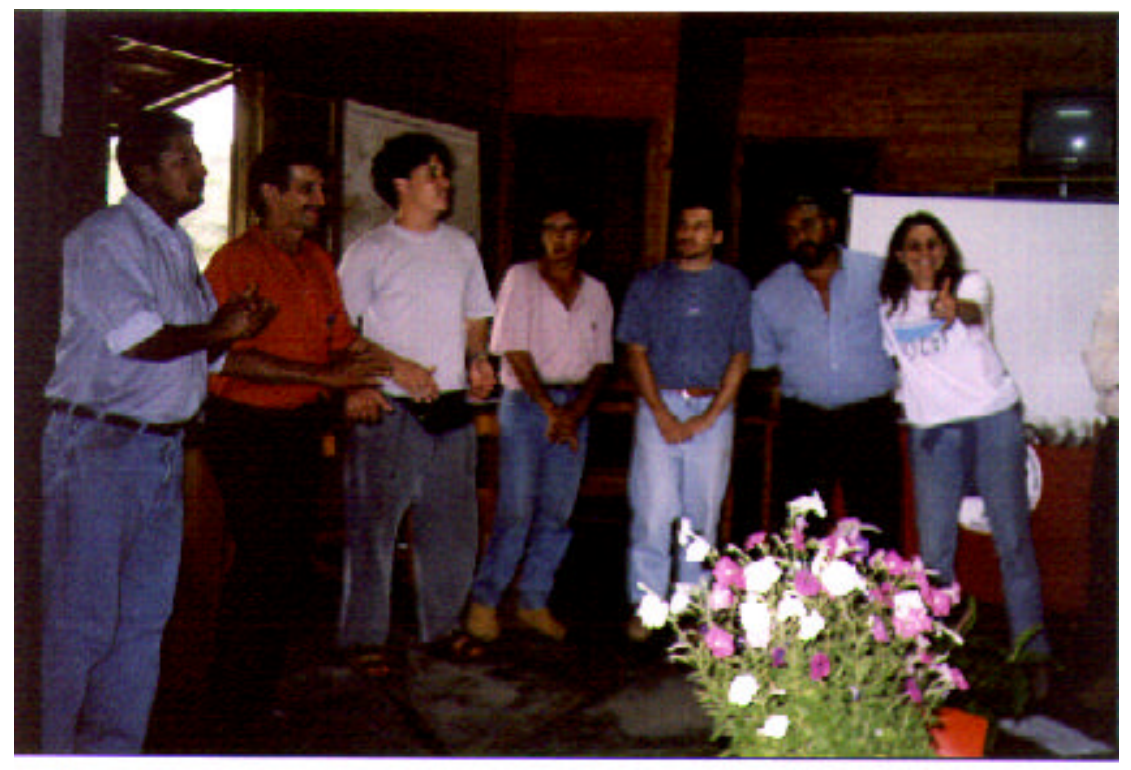

A participação do pesquisador em seminários promovidos pelas organizações também foi um instrumento de análise interessante. Nesses seminários puderam ser apreendidos aspectos da realidade que dificilmente seriam captados através de entrevistas formais com os participantes.

$\mathrm{Na}$ foto acima, participantes do Seminário sobre Reforma Agrária e Agroecologia, realizado na sede do Parque Estadual do Morro do Diabo. 